\title{
SEBASTIAN DE HOROZCO Y EL LAZARILLO DE TORMES
}

En I867 publicó el erudito sevillano José María $\Lambda$ sensio y Toledo el primer estudio y edición de algunas obras de Sebastián de Horozco, ingenio toledano del siglo XvI, retrasado poeta de cancioneros y padre del lexicógrafo Covarrubias. Interesado Asensio por su aspecto de primitivo de nuestro teatro, daba a conocer, en un pulcro librito ${ }^{1}$, un entremés y dos representaciones, una de las cuales era La historia evanjélica del capitulo nono de Sanct Joan. Al imprimirla, advirtió Asensio, en nota a pie de página, la semejanza que, "hiasta en algunas de las expresiones" ${ }^{2}$, presentaba cierto pasaje que relata las picardías de un mozo de cieg o llamado Lazarillo, con las aventuras más conocidas de su homónimo de Tormes; formulada la posibilidad de que ambas obras hubieran salido de una misma pluma, remitía la solución al hallazgo de ese Libro de Cuentos que conocía Tamayo de Vargas y por cuyo descubrimiento seguimos suspirando también hoy, aunque su mera noticia tenga, de todas formas, un precioso valor para nosotros, en cuanto nos permite afirmar que el Licenciado Sebastián de Horozco cultivó indudablemente el género novelístico, al que, en grado muy notable, le impulsaban sus aficiones ${ }^{3}$.

1 José maria Asensio y Toledo, Sebastián de Horozco. Noticias $y$ obras inéditas de este autor dramático desconocido. Sevilla, imp. Geoffrin, 1867 .

2 ASENSIO, op. cit., p. 46, nota $x$.

3 Las múltiples relaciones de festejos y sucesos particulares de Toledo, que se entretenfa en escribir con delicioso estilo descuidado y familiar, muestran sus cualidades de narrador amigo de entremeter 
RFE, XLI, 1957

La duda permanecía en el aire cuando el benemérito Asensio hizo del interesantísimo Cancioncro de Horozco un volumen de la colección de los Bibliófilos Andaluces, que apareció en I8 $74^{1}$. No estudió el problema Menéndez Pelayo, a pesar de haber dedicado a Horozco un breve, aunque enjundioso, esbozo crítico, donde señalaba las cualidades que hubieran hecho de él un excelente narrador y que hacían doblemente lamentable la pérdida del Libro de Cuentos ${ }^{2}$. Pero muchos años después, en I9I4, Julio Cejador y Frauca, en una edición del Lazarillo $^{3}$ que viene reimprimiéndose - como si no hubiese llovido desde entonces-, lanzaba una teoría ambiciosa: el Licenciado Sebastián de Horozco debía ser el autor de la más interesante novela del siglo XVI y creador por tanto del género picaresco.

Para llegar hasta una conclusión de tal envergadura se basaba Cejador en la similitud de las burlas al ciego, además de otras semejanzas temáticas (amancebamiento de clérigos, almuerzos a orillas del Tajo, oraciones de ciegos) y también en la presencia de giros expresivos comunes y cierto número de coincidencias de léxico. Cejador comprobó cómo, en efecto, una comparación sistemática con las obras de Horozco servía a las mil maravillas para ilustrar una edición crítica del $\mathrm{La}$ zarillo de Tormes. Previamente había empleado también una vía de selección negativa que le autorizaba a ir descartando

opiniones propias, siempre punzantes e impregnadas de un peculiarísino humor satírico, del que hemos de citar algunas muestras.

1 Cancionero de Sebastián de Horozco, poeta toledano del siglo XVI. Scvilla, imp. Tarascó. I874. Sociedad de Bibliófilos Andaluces, primera serie. Como introducción se insertan dos cartas dirigidas a Asensio por Antonio Martín Gamero en 1873 , con noticias y apreciaciones en torno a Horozco. Se añadia también una nota bibliográfica sobre manuscritos con papeles y relaciones toledanas del mismo autor, conservados en la Biblioteca Nacional y en la de Palacio. A esta edición nos referimos al citar Cancionero.

2 Marcilino meníndez Pelayo, Origenes de la novela, vol. III, Santander 1943, ed. nac., pp. 91-92.

3 Clásicos castellanos de "La Lectura". Madrid, I914. 
otros posibles autores, aunque con una superficialidad de argumentación e insuficiencia metodológica, que hacen por completo inaceptable dicho fundamento de su teoría.

Cejador parece haber obtenido con esto sólo un éxito momentáneo, pues, aunque sus conclusiones fueron aceptadas por Bonilla y acogidas con simpatía por Rodríguez Marín ${ }^{1}$, cabe advertir, por lo denuás, una general reserva, inducida en primer término por su insuficiente formulación y quizás también por el no muy boyante prestigio científico de su autor.

Poco tiempo después, en I9I5, la teoría de Cejador se veía muy duramente combatida por Emilio Cotarelo, que tuvo el buen acterdo de comenzar la publicación de otra obra inćdita de Horozco, un interesantísimo Libro de proverbios o Refranes glosados, según la copia que posee la Real Academia Española, en ctryo boletín vino dándose a conocer ${ }^{2}$ hasta su brusca e inexplicada interrupción. En el estudio introductorio sostenía Cotarelo un argumento fundamental para negar la paternidad de Horozco: éste no tendría arriba de unos diez y seis años cuando se redactó el Lazarillo.

Desde entonces el abandono de la teuría de Cejador ha sido casi absoluto, debido sobre todo a la boga, poco menos que geileral, de la antigua atribución a don Diego Hurtado de Mendoza, múltiples veces defendida por la erudición del llorado González Palencia ${ }^{3}$. Y no obstante ha llegado el momento de

1 Cuidó muy bien de afirmarlo el propio CEJADOR en las últimas líneas de su introducción. Ed. cit., p. 75.

2 Emilio Cotarelo, Refranes glosados de Sebastian de Horozco. El Licenciado Sebastián de Horozco y sus obras, BRAE, t. II, 1915, páginas 646-706; III, I9I6, pp. 98-132, 399-428, 591-604, 710-721; IV, I917, pp. 383-396. En las citas nos referimos al tomo y año en núueros romanos, seguidos de las indicaciones de página y numero de orden del refrán.

3 Puede verse su estudio preliminar a la ed. del Lazarillo en "Clásicos Ebron, Zaragoza, I940. En Vida y obras de don Diego Hurtado de Mendoza, t. III. Madrid, 1943, pp. 206-222. Leyendo el "Lazarillo de Tormesn. (Notas para el estudio de la novela picaresca), Escorial, XV, 1944, pp. 9-46. 
reflexionar sobre el modo como se ha razonado a favor de don Diego.

Advirtamos en primer lugar el carácter negativo de casi toda la tesis. No da González Palencia verdaderas razones que demuestren la viabilidad de la atribución, sino que se limita a insistir, una y otra vez, en la futilidad de las objeciones que le han sido formuladas, sobre todo por Morel-Fatio'. Se procura poner de relieve que la paternidad de don Diego no es improbable ${ }^{2}$ y, para mantener su posibilidad, ha de recabarse, tengámoslo muy en cuenta, una localización cronológica rerelativamente tardía, centrada sobre $I_{538}$, fecha de las discutidas Cortes a que se alude en las palabras finales del relato de Lázaro.

El único argumento de carácter positivo queda reducido a la afinidad del espíritu desenfadado y mordiente del Lazarillo y el que impregna la correspondencia privada de Hurtado de Mendoza, si bien Morel-Fatio había opuesto ya ciertas dudas al valor de dichas semejanzas: "Car si, entre autres, ses dépêches contiennent quelques morceaux vivement enlevés, il s'en faut de beaucoup qu'on y retrouve, en général, la manière sobre et si savoureusement concise de la nouvelle» ${ }^{3} ; \mathrm{y}$ hasta el mismo González Palencia ha observado en alguna ocasión la lejanía estilística que, en el fondo, se da entre don Diego y el autor del Lazarillo: "No puede hacerse gran hincapié en el aspecto estilístico del Lazarillo para compararlo con los escritos de Mendoza: el estilo seco, cortado y conciso del Lazarillo concuerda con el de estas cartas de Mendoza y con otras obras en prosa suyas. Pero acaso no se le pueda y deba dar gran valor a este punto, teniendo en cuenta que tales escritos, en forma de postdata, y para comentar una no-

1 A. Morei, Fatio, Etudes sur l'Espagne, París, 1895, première série, II, Recherches sur Lazarille de Tormes, p. I43 y sigs.

2 A. Gonzílez Palencia, ed. cit., p. I3.

3 Op. cit., p. 157. 
ticia o un suceso, habían de escribirse forzosamente de prisa, en forma abreviada, rápida y nerviosa» ${ }^{1}$.

Pero tampoco remueve, ni aun menciona, González Palencia el más serio obstáculo de los propuestos por Morel-Fatio, y según el cual Schott y Taxandro se limitarían a recoger el rumor de la paternidad de don Diego siguiendo la costumbre de la época en atribuirle toda suerte de obras atrevidas, obscenas o insolentes, como ocurrió en el caso concreto de las Cartas de los Catarriberas de Eugenio de Salazar².

Finalmente, hemos de mencionar aún la aparición de dos nuevas tendencias enfocadas a resolver el problema que nos ocupa. La primera, defendida por el gran hispanista Mr. Bataillon, que, al abordar al Lazarillo en sus relaciones con el erasmismo, vuelve a tomar en cuenta otra atribución tradicional, la formulada por el cronista de los Jerónimos Sigiien$z a$, que señala como autor a fray Juan Ortega ${ }^{3}$.

1 Leyendo el "Lazarillo de Tormes", p. 36. P.joo después concluye también aqui que la atribución a Hurtado de Mendoza no es improbable:

2 "La vérité, la voici. On a rapporté Lazarille a Mendoza, parce que de bonne heure s'était formée autour de son nom comme une légende, parce que sa morgue, son esprit vif et indiscipliné, ses boutades et ses saillies lui avaient valu, en littérature, une réputation d'enfant terrible». Op: cit., p. I 57. Y también: «Don Diego a endossé la responsabilité d'oeuvres où il n'a jamais mis la main: non seulement Lazarille, mais d'autres écrits de moindre importance, lettres satiriques ou pamphlets littéraires. Son nom, toujours en faveur, assurait aux libelles anonymes une vogue surprenante. Inutile de rechercher plus loin. La tradition qui imposse Lazarille a M ndoza n'a pas d'autre fondement que ce besoin de mettre un nom connu, populaire sur un livre que son véritable auteur a, pour un motif qualconque, évité de signer. On chercha, au comencement du XVII siècle ou peu avant, le nom qui se prêtait le mieux à couvrir une marchandisa sans propiétaire, et, Mendoza s'étant offert, ce fut lui qu'on prit». Op. cit., p. I 58.

3 Bataillon rechaza por completo la teorla de Cejador: se basa solamente en el episodio del ciego común a la Representación evangélica y al Lazarillo, explicable porque ambos debían manejar una materia folklórica común. La atribución a Fray Juan de Ortega "ne souleve aucune objection graven. Le roman picaresque, París, I93 I, pá- 
La segunda se encamina a buscar y airear nuevos candidatos y encarna en los estudios de Arturo Marasso', que no. llega siquiera a proponer, sino más bien a insinuar, con toda suerte de precauciones, la velada figura del humanista soriano Pedro de Rúa.

\section{UNA TEORIA REBATIDA}

Pero convienc volver atrás para plantearnos la cuestión de la legitimidad y validez de la impugnación de Cejador por Cotarelo.

Todos, nosotros mismos, estamos dispuestos a aceptar, desde luego, la insuficiencia que, casi unánimemente, ha sido señalada en ella ${ }^{2}$. Ciertos -y pocos- pasajes tomados de obras cuyas fechas resultan desconocidas y que pueden ser -quién sabe- incluso posteriores al mismo Lazarillo, algún uso expresivo, alguna que otra coincidencia lexicográfica, no parecen base muy suficiente para comprometerse a una atribución de tanta monta. Si, en efecto, Cejador hubiese agotado, como pensaba González Palencia ${ }^{3}$, los argumentos en favor de Horozco sin apoyarse más que en los datos que expone en

gina 9. En su magna obra sobre Erasmo y España vuelve a insistir en lo inaceptable de las hipótesis de don Diego y Horozco (Erasmo y España, México, 1950. T. II, p. 212, nota 3, y 21 5, nota 10) Bataillon ve un argumento a favor de Ortega en el hecho de que en el Lazarillo se zahiera con mayor ensañamiento a los clérigos seculares precisamente. Bataillon ha vuelto a defender hace foco la posible paternidad de Ortega en El sentido del Lazarillo de Tormes. París 1954.

1 La elaboración del Lazarillo de Tormes y Aspectos del Lazarillo de Tormes, publicados en Estudios de literatura castellana, Buenos Aires I955.

2 A. Gonzalez Palencia, ed. cit., p. i2.

3 "Cejador agotó tóda clase de argumentos para clemostrar la paternidad de Horozco, sin conseguirlo, por desgracia: D. Emilio Cotarelo, en una sola página, deshizo el imponcnte tinglado que levantara Cejador." Leyendo el "Lazarillo de Tormes", p. 29. Casi con las mismas palabras se expresa al redactar su articulo para la última edición del nanual Historia de la Literatura Española. 
su edición del Lazarillo, habríamos de considerar la atribución como hipótesis de no excesivas probabilidades, aunque tampoco creemos que pudiera rechazarse de plano. Pero aquí está el gran error que invalida todo el razonamiento antes expuesto: Cejador no agotó, ni con mucho, los múltiples filones que nos ofrece la obra del ingenio toledano. Más aún: podemos afirmar que la manejó con la misma ligereza que mostró en el estudio de otros temas, pues hasta su lectura del Cancionero, no parece haber pasado de entretenida y volandera. Con todo esto, creemos que condenó al fracaso una idea fecunda, cuyo mérito somos los primeros en reconocer en toda su amplitud.

El gran argumento con el que Cotarelo se atreve a rechazar sin paliativos la teoría de Cejador, es, sin embargo, de muy distinta naturaleza; como dijimos, cree que la fecha de redacción del Lazarillo puede colocarse con seguridad entre los últimos meses de 1525 y los primeros de 1526 , es decir, cuando Horozco no pasaba de ser un mozalbete ${ }^{1}$.

Pues bien, examinemos sus probabilidades de acierto. Empieza por observar la cronología de-la vida de Lázaro, que, correctamente, considera iniciada sobre 1502 y terminada, en la novela, con una alusión a los regocijos con que se festejó, en Toledo, la venida del Emperador para celebrar unas Cortes. Y estas Cortes no pueden ser más que las celebradas en abril de 1525 , pues la posibilidad de alusión a las de 1538 queda eliminada por la circunstancia de que, según Cotarelo, se desarrollaron en un mal ambiente que no daría mucha ocasión a regocijos y festejos. Tal convencimiento encuentra apoyo en el hecho de que Lázaro afirme que "cierto en aquel tiempo no me devían de quitar el sueño los cuydados de el rey de Francia» ${ }^{2}$, frase que cree también alusiva a la prisión de Francisco co I en Pavía, por aquellas fechas; pero donde no somos no-

1 Op. cit., II, pp. 683-687.

2 Ed. CEJADOR, Madrid, rgr4, p. I5I. A esta erlición referiremos las demás citas del Lazarillo, expresando el número de página entre paréntesis a continuación de los textos. 
sotros los primeros en no ver más que una frase tópica de uso conversacional ${ }^{1}$.

Observemos que la identificación de las Cortes resulta de lo más dudoso, pues no cita Cotarelo ningún dato en que apoyar su creencia de que no se hiciera algún regocijo y fiesta por la llegada del Emperador. ( $\mathrm{Y}$ pensemos además que, con todo, González Palencia insiste en que las Cortes mencionadas son las de 1538 ). En realidad es punto menos que imposible averiguar a cuál de las dos Cortes se refiere Iázaro, ya que éste no da la menor indicación respecto a la edad que tiene en el momento de terminar su relato. Pero es más: aunque estuviésemos seguros de que se alude a las Cortes de I525, en modo alguno podríamos deducir que el Lazarillo hubiese sido es-

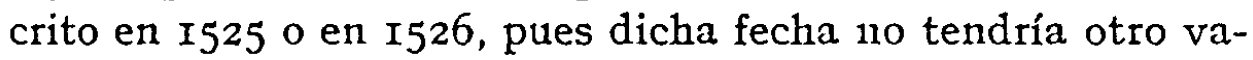
lor que el de término post quem, ya que el autor pudo haber estudiado de intento la cronología de la acción, en tanto mayor grado cuanto todo esfuerzo por alejar los hechos en el tiempo no sería más que un acto de elemental prudencia, tratándose de una obra tan corrosiva y con delaciones personales tan peligrosas como la muy concreta del Arcipreste de San Salvador. En el caso de Horozco no tendría esto absolutamente nada de particular, ya que estamos ante un auténtico cronista local, perfectamente enterado de la grande y pequeña historia toledana, amigo de coleccionar documentos y harto aficionado a la lectura y recopilación de historias ${ }^{2}$.

1 "Tampoco puede conjeturarse enteramente que la frase: aen aquel tiempo no me debian de quitar el sueño los cuydados de el rey de Francian se refiera a la prisión, en 1525, después de Pavia; estos legendarios "cuidados del rey" pueden quizá encontrarse en un romance, en una expresión popular, en un cuento de ciclo carolingio.n MAARAsso, La elaboración del Lazarillo de Tormes, p. I6o. Su carácter de alusión retrospectiva disminuye también, a nuestro parecer, dicha posibilidad.

2 Entre las Relaciones de Horozco hay una dedicada a las Cortes de $153^{8}$ precisamente. Al reducirse a una enumeración de procuradores en su parte principal, deja también sin resolver lo de los regocijos. 
Más aún: estamos seguros de que en un caso concreto recurrió Horozco a semejante artificio; en la Representación de la parábola de Sant Mateo a los veynte capitulos de su sagrado evangelio hay un echacuervo que presenta una bula "concedida por León" $\dot{y}$ que al parecer no puede referirse sino a la de I $\mathrm{x} 7$ que dio origen a la herejía luterana, fecha a la que sería absurdo referir una obra que sabemos no pudo materialmente ser escrita hasta muchos años después.

Lo más curioso, como vemos, es la inconsecuencia de González Palencia al acoger la fecha tardía -más verosímil, desde luego- de las Cortes de 1538 , puesto que de otra forma se le haría muy difícil la defensa de su atribución, lo que, sin embargo, no le impide dar por válido el razonamiento de Cotarelo contra la teoría de Cejador ${ }^{1}$. Según palabras de González Palencia derribó aquél en una sola página el imponente tinglado -jun poco menos!- construído a favor de Horozco. Una opinión tan radical e inconsistente, que, por desgracia, pasó incluso a los manuales de literatura española, ha contribuido a formar una auténtica barrera de infundados prejuicios contra la atribución a Horozco.

\section{EL PROBLEMLA DE LA FECHA}

En todo el problema que nos ocupa es, pues, esencial tener una idea clara acerca de la posible fecha de redacción, sin to cual nos expondremos a pisar siempre un terreno res-

1 Es curioso cómo la tesis favorable a Hurtado de Mendoza ha presenciado muy pronto un intento de modificación por parte de LUis JAINE Cisneros en su ed. del Lazarillo de editorial Kier (Buenos Aires, 1946). Cisneros disiente vivamente de González Palencia en este punto crucial de la fecha de redacción, pues estima que las Cortes aludidas son las de 1525 , y que, según esto, pudo salir cierto el rumor de que el Lazarillo lo escribió don Diego cuando era estudiante en Salamanca. Sus razones son demasiado sutiles para que podamos exponerlas con detenimiento. Sólo vamos a exponer dos objeciones. 
baladizo en el más alto grado. Por ello nos detenemos para fijar debidamente nuestro punto de vista.

Como hemos apreciado, ning ún clato de índole externa permite, hasta ahora, el establecimiento de una fecha tan temprana como la propuesta por Cotarelo. Por lo demás, cualquiera que se halle medianamente familiarizado con el ambiente literario de nuestro siglo xvi podrá advertir el trastorno de conceptos que traería consigo una aparición tan precoz de las fortunas y adversidades de Lázaro. Se necesita que el erammismo haya penetraclo profundanente, casi hasta un nivel de vulgarización, para poder explicarnos la génesis y posterior éxito del Lazarillo, según ha observado la autoridad máxima de Bataillon, que se inclina a fecharlo entre 1530 y I540. Lengua y estilo presentan también una ductilidad revolucionaria para pertenecer a los primeros años del reinado cle Carlos V, y no a los últimos'.

I a escasez de probabilidades a favor de la fecha de Cotarelo se hace todavía más visible si comparamos al Lazarillo con una obra demasiado olvidada por la crítica, y cuyo interés ha de subir más y más cuando nos planteemos de veras el pro-

Ia primcra, que ni siquiera sabenos con certeza que don Diego estudiase en Salamanca. In segunda, la imposibilidad de que una obra así haya nacido en el cercbro de un cstudiante de veintidós años. Ja disidencia de Cisneros nos parece un signo evidente de la debilidad interna que aqueja a la tesis favorable a Hurtado de Mendoza.

1 "Un nuevo lenguaje de la narración se desarrollaba ahora, a mediados del siglo Xvi". "En este estilo llano, propio para la piatura de escenas de la vida ordinaria, parecido al que cincuenta años más tarde empleará Cervantes, es el Lazarillo admirable modelo." RAnión Misióndez Pidat, A utologia de prosistas españoles, Buenos Aires i95I, pírinas 69 y 7 o. Uno de los muchos arcaísmos del toledanisimo lenguaje de Horozco era precisamente la mención sin artículo de los nombres de ríos, por lo que no sirve este rasgo para relegar el Lazarillo a la primera mitad del xvr. "Tajo por esta ciudad venía tan baxo" decía Horozco al comentar sucesos de 1561 . CONDE DE CEDIr.LO, Algunas relaciones y noticias toledanas que en el siglo XVI escribia el Licenciado Sebastián de Horozco. "Bol. de la Soc. Española de Excursiones", t. XIII (1905), página 185 . 
blema de los orígenes del género picaresco; nos referimos a $L a$ Lozana andaluza. Que entre ambas obras existe una relación, nos parece hecho palpable, imposible de soslayar. Además de una atmósfera de sátira y picaresca que lo impregna todo, encontramos en La Lozana una enorme cantidad de sugerencias que parecen haber sido desarrolladas después por el seguro instinto técnico del autor del Lazarillo. En momento de apuro, 1a Lozana guarda sus anillos en la boca; hay un fraile de la Merced que anda por sitios de lo más inconveniente; ensalmos para curar golpes en la cabeza; ataques contra las bulas; mención proverbial del infame lecho de alquiler, así como de las confituras de Valencia; hidalgos pobres; ambiguas curanderías; criados que van por vino y candelas; reverentes saludos con el bonete; amenazas de jarrazos; uno que se pavonea de no ser "de los ínfimos de mi tierra»; rezadoras de oraciones para casar y parir; criados despedidos por desmandarse en comer; lavanderas pícaras; mozos que buscan amos; canónigos amancebados; gentilhombres que se excusan como pueden para $n o$ dar un cuarto a damas; criados que roban la cebada de las bestias; otro que come, bebe y triunfa sin tener envividia del Papa; amén de bastantes expresiones comunes tales como tan blanco el ojo, entrar por contadero, nunca en tal me vi. La sistematización de las muchas coincidencias que despiertan nuestra curiosidad es una labor tentadora, pero que por extensa no podemos acometer en este momento.

Que el influjo no va en sentido Lazarillo-Lozana nos parece confirmado por el hecho de que en la segunda se menciona a un Lazarillo que nada tiene que ver con el de Tormes y sí con ese oscuro fondo proverbial y folklórico de que se lia desprendido la figura de nuestro infortunado mozo de muchos amos. Con ello tenemos un argumento de fuerte probabilidad en abono de que el Lazarillo no era todavia conocido en I528, fecha más que verosímil de la redacción de La Lozana ${ }^{1}$. Horozco,

1 No lo afirmamos a humo de pajas. Aunque suele aceptarse habitualmente la fecha que el autor mismo tiene cuidado de darnos y según la cual terminó su obra el I de diciembre de 1524 , las continuas alusio- 
gran aficionado a la lectura y composición de todas aquellas "obras de burlas" que entonces no escandalizaban a nadie ${ }^{1}$, conocía y utilizaba a menudo la inagotable enciclopedia de obscenidades contenida en La Lozana.

Eil caso no es único, porque todas las fuentes que han podido señalarse apuntan insistentemente hacia fechas no muy anteriores algunas a la de la aparición impresa del Lazarillo. Observemos los años de impresión de algunas de las posibles fuentes que Marasso ${ }^{2}$ ha logrado señalar. Ciertos contactos con Pero Mexía parecen imposibles antes de I540; la cita de Plinio pudo derivar de una obra que vió la luz en I540, así como la de Cicerón pudo tomarse de otra de Cervantes de Salazar, en cuyo caso el Lazarillo "no pudo ser escrito antes de I546"; resulta probable que el autor tuviese noticia de la Iliada en la traducción de Gonzalo Pérez, conocida a partir de I550; muy peculiar relieve hemos de conceder a la presencia de ciertos refranes que contiene el Libro de Refranes de Pedro de Va-

nes a las venideras calanidades del saco de Roma muestran bien a las claras haberse escrito después de tal acontecimiento, es decir, entre el mes de mayo de 1527 y su aparición en 1528 . Esto nos parece esencial para comprender el sentido de La Lozana, "historia compuesta en retrato, el inás natural que el autor pudo" (ed. "Colección de libros raros y curiosos", Madrid, I87I, p. 329) es decir, realidad viva, sin quitar ni poner, retrato en suma. Lo cual equivale a decir: esto era esa Roma que acaba de perecer en el saco, la calamidad que sus pecados venfan profetizando. De csta forma, La Lozana no recoge solamente la postura de cinismo vital común a ciertos sectores del Renacimiento italiano, sino que pasa a insertarse por completo en la amplia e ilustre literatura encaminada a justificar el saco de Roma.

1 I,os pudibundos bibliófilos andaluces tuvieron que reducir a lineas de puntos ciertas composiciones del Cancionero. Al mismo recurso hubo de atenerse el Conde de Cedillo para publicar las relaciones toledanas. Al describir las fiestas con que se solemnizó la conversión de Inglaterra en $\mathrm{x} 555$, comenta Horozco después de detallar lo que hacia cierta mogiganga que salió por las calles de Toledo: "Con que tampoco llorava la gente, ni aun las damas que los veyan". CEDILLO, op. cit., p. 173 .

2 La elaboración del Lazarillo de Tormes, p. 160 y ss. 
llés (Zaragoza I549), cuyo prólogo ofrece también alguna concomitancia con el de Lázaro, ya que sabemos que Horozco manejó, según confesión propia, todas las colecciones y repertorios paremiológicos de su tiempo ${ }^{1}$.

Aunque, por supuesto, ninguno de estos argumentos permita fechar el Lazarillo, es curioso observar cómo apuntan y confluyen hacia fechas tardías. $\mathrm{Y}$ también resulta significativo que la única opinión favorable a Horozco formulada en los últimos años, derive, en igual forma, de un abordaje erudito al problema de las fuentes. J. E. Gillet toma en cuenta la viabilidad de una no anterior a 1547 ; consiste en un fragmento de un Liber vagatorum flamenco que contiene una versión cercanísima a los engaños del echador de bulas y que tal vez permitiera zanjar definitivamente el problema si dicha fuente no. constituyese, a su vez, otro enigma de difícil desenredo². Desde sus puntos de vista sospecha Gillet si no estaremos ya muy cerca de resolver los problemas del Lazarillo en cuanto a atribución y bibliografía, por lo que añade: "On the other hand, internal evidence makes Sebastián of Horozco a likely candidate for the authorship of the Lazarillon ${ }^{3}$.

1 "Si assi, secamente, sin les dar alguna glosa y entendimiento to hobiera de hacer, copilación y volumen, ciertamente yo juntara, como en otras lo tengo juntado, mucho mayor número que todos». II, página 696.

2 A note on the Lazarillo de Tormes. MLN, LV, 1940, pp. I $30-134$. La fuente propuesta ofrece dos valiosos detalles no conteniclos ell el Novellino de Masuccio de Salerno, comúnmente aceptado como origen del episodio del buldero: el soborno y captación de los curas y la rabia espumajeante con que se castiga en la iglesia la supuesta calumnia del cómplice. La obra de referencia parece que no se imprimió hasta 1563, en Amberes, aunque por tener una aprobación dada en Bruselas en septiembre de 1547 , estina Gillet que debió ser conocida ya alrededor de esa fecha, con lo cual estamos de nuevo en el incómodo terreno de las presunciones. Con muy buen olfato sugiere Gillet si el parentesco de Horozco con la familia Egas, a que pertenecia su mujer, no le haria mantener ciertas relaciones con Flandes, lo que tambićn puede ayudar no poco para comprender la misteriosa y sostenida sucesión de las ediciones antuerpienses.

3 op.cit., p. 134. 
Como se ve, toda investigación seria conduce insistentemente hacia fechas tardías, no muy alejadas de su salida impresa en I554. Nuestra opinión particular es que una obra como el Lazarillo no puede tardar mucho tiempo en ser ampliamente divulgada y en dejar inevitables huellas de que, hoy por hoy, carecemos en absoluto. No estamos ante un libro que pueda estar quieto mucho tiempo en gavetas ni estanterías, puesto que ni la dura y peligrosa mano inquisitorial pudo frenar su difusión. $\mathrm{Y}$ además es preciso que valoremos como es debido el hecho indudable de que Juan de Junta, impresor de la edición burgalesa que Morel Fatio y González Palencia consideran princeps, sacase también de sus prensas una obra de Iorozco, sin nombre de autor, para mayor coincidencia, en $155^{2}$, extremo que parecía ya "muy singular" al mismísimo Cotarelo ${ }^{2}$, que lo hubiera considerado favorable a Horozco a no encontrarse muy seguro de que el Lazarillo se escribió en 1525 o, todo lo más, en 1526 .

\section{TOLEDO}

Pero hasta ahora no hemos pedido su opinión al propio texto de la vida de Lázaro. No nos niega, en primer término, el lugar de su redacción, que, evidentemente, es Toledo. Cuando el ciego se llevó a Íázaro de Salananca «su motivo fué venir a tierra de Toledon (p. 105) y cuando el lacerado huyó del clérigo de Maqueda udi comigo en esta insigne ciudad de Toledo" (p. I65).

'́odos los datos contribuyen a robustecer esta idea del to-

1 i'uede verse su descripción en Catúlogo de la biblioteca de Salvá. Valcncia, 1872 , t. II, p. 222, n. 2 109. Se trata de ese Libro del nimero seficnario que incluye la lista de las obras de Horozco formada por Tamayo de Vargas y reproducida por NICOL $\Lambda$ s ANTONIo en Bibliotheca Hispana Nova, Matriti, 1788, t. II, pp. 281-282. Reproducimos cn este artículo la portada y cl colofón del ejemplar del Britisl Museum. Damos las gracias a $\mathrm{D}$. Xavier de Salas por su interés personal en la obtcnción del microfilm.

2 Op.cit., p. 683, II. 
ledanismo integral del Lazarillo. Su autor conoce muy bien Salamanca y Toledo, además de los pueblos situados en el camino más directo entre ambas ciudades, es decir, los que atravesaba un estudiante toledano para ir a Salamanca en el siglo $\mathrm{XVI}^{1}$ y a los que nuestro buscado autor aplica, con toda exactitud, la terminología de villas, lugares, señoríos, etc. Inn cambio, la localización de las andanzas se hace más imprecisa a medida que tienden a alejarse del núcleo toledano. No concreta ya nada en dirección NE, pues se contenta con mencionar sólo "un lugar de la Sagra de Toledo» (p. 229); lo misino que hacia el SE, donde tampoco especifica nada: "Nos fuymos hasta otro lugar de aquel, cabo de Toledo, hazia la Mancha» (p. $247-248$ ).

Hemos, pues, de contradecir rotundamente las opiniones de González Palencia, según las cuales Toledo aparece en el Lazarillo "desdibujado e impreciso" ${ }^{2}$, como un fondo más o

1 Puede comprobarse mediante el Repertorio de todos los caminos đe España, publicado por el valenciano JUAN VIr.Luga en i 546 , basado en el cual publica un interesante gráfico Gonzalo MENíndez Pinar, en Los caminos en la historia de España, Madrid, 195I, p. 85.

2 "No parece que conocia mucho a Toledo el autor, o anduvo muy descuidado. Para que fuera el criado tan pronto al río se deduce que estaba cerca: tenia que ser por la bajada del Pozo Amargo, o sitio cercano. Pero en aquel sitio del río Tajo no hay huertas, ni frescas riberas, ni por aquellos vericuetos y peñascales irfan dannas enamoradas, ni esto ocurrirfa a las primeras horas de la mañana. Una vcz más cl Toledo pintado en esta llamada obra realista es tan falso como el de las églogas y las novelas pastoriles. Si se fija la atención en las breves pinceladas dedicadas a describir este 'Toledo por cuyas calles y plazas paseaba su garbosa figura el hidalgo, se convence uno fácilncn te de que no tiene valor descriptivo alguno, y que lo mismo puede tratarse de Toledo que de otra población cualquiera. Compárese este Toledo desdibujaclo e impreciso del Lazarillo con cl Toledo bullicioso y animado de La ilustre fregona, y se comprobará una vez más la falta de realismo en la prinera de nuestras novclas picarescas". Ley'cndo el "Lazarillo de Tormes", pp. 24-25. Como se ve, González Palencia ha qucriclo extraer demasiado jugo al dato referente a la bajada de I ázaro, puesto que lo de los almuerzos y paseos junto al Tajo es dato concreto que comprueba el Cancionero del mismo Horozco. Pensemos en lo rela- 
menos convencional. E1 autor conocía Toledo muy bien; sabía esas cosillas que sólo ve quien ha vivido mucho tiempo en una ciudad o ha nacido en ella. Emplea con discreción el nombre de "Ayuntamiento" que por muy especial honor usaba la municipalidad toledana. Sabe cómo se legislaba allí contra los pobres y que las sentencias se ejecutaban por las Cuatro Calles ${ }^{1}$. La industria bonetera, los imprescindibles aguadores $y$ muchos otros detallitos del pulso cuotidiano de la ciudad se ven continuamente reflejados en el Lazarillo. Se advierte también el deseo del autor de zaherir y hacer rabiar a los paisanos, de echarles en cara su poca caridad ${ }^{2}$, los vicios de sus hidalgos, demasiado aficionados a no santas diversiones y galanteos a orillas del Tajo ${ }^{3}$, de meterse con la virtud de las

tivo de la noción vulgar de ticmpo, amén de nuestra ignorancia del emplazamiento auténtico de la casa, que el autor no especifica nunca. Concedemos, sin embargo, la falta de una intención descriptiva, que es precisamente lo que da todo su valor al continuo aflorar de referencias toledanas.

1 De la relación de las ceremonias con que se alzaron pendones por Felipe II en 1556: "Los sofieles con sus maças y los jurados y rregidores por su horden y antiguiedad fueron por la lonja y quatro calles y calçeteria y lençerfa y calle ancha hasta Çocadovern. CONDE DE CEDILLO, Toledo en el siglo XVI después del vencimiento de las Comunidades. Madrid, rgor. Apéndice V, p. 177.

2 También en el ciego de la Historia cvanjélica se da la lamentación por la falta de caridad. Ante la inutilidad de la invocación de su amo ("Ay quien haga caridad / señores, a aqueste ciego...n), Lazarillo hace con un refrán su filosófico connentario: "Es llamar al rey compadre / vozearn. Cancioncro, p. 157.

3 El primer incurso en censura era el mismo Horozco, que acostumbraba a reunirse con ciertos amigos, entre los que figuraban el licenciado Diego Sánchez y el pintor Comontes, para despachar abundantes almuerzos "en la güerta con la fría / por donde Tajo corria». La descripción de la comilona tiene por cierto alguma salida casi gongorina: "El tocino les da alientos / de un jamón como un coral». No se habla de danias, pero tampoco debian de faltar, según lo que puede deducirse de las costumbres de Horozco y sus amigos, que se divertían de lo lindo con alusiones a las bubas de cada cual. Para todo lo de los almucrzos, véase Cancionero, pp. 2 ro-212. 
mujeres ${ }^{1}$ y sus lucios abades amancebados. Toledo no es así un telón de fondo, mejor o peor pintado con pretensiones de color local, es una realidad omnipresente, de la que el autor no tiene siquiera que preocuparse debido a que está ahí.

\section{UN JURISTA}

Adelantamos en este punto algunos resultados del estudio linguístico que traemos entre manos y que nos permiten apreciar la penetración en el Lazarillo de un habla técnica, dato inapreciable para ayudar a la identificación de su autor, que deja transparentar, muy a menudo, el latiguillo escapado del formulario jurídico, como ocurre en el caso de los padres de Lázaro a cuyos nombres se une en seguida la coletilla unaturales de Tejares, aldea de Salamanca" (p. 77-78). Lo mismo ocurre con la expresión "se le escriva y relate el caso muy por extenso" (p. 74), por no decir nada de ese directe ni indirecte que se le escapa en una ocasión. Aire de protocolo trae también el escudero cuando nos dice, tan serio: "Yo me obligo con ella cercenar un copo de lana» (p. I80) ${ }^{2}$. Y en el juego de palabras entre significado técnico y significado vulgar: "Hazen cuenta y de dos meses le alcançaron lo que él en un año no alcançara» (p. 2I8). Con todo lo cual podemos explicarnos, además, por qué el Lazarillo se exprèsa sobre determinadas realidades empleando el mismo vocabulario que los cuadernos de Cortes

1 Menos mal que alguna vez también piropeó Horozco a sus paisanas. Las mujeres lindas deben ser amadas, "mayormente toledanas / que eceden en ser hermosas". Cancionero, p. 75 .

2 Acerca de su caránter formulario bastará citar algunos textos de Horozco. "No consta ser obligado / al dicho virgo ninguno" Cancionero, p. 99 (se imita precisamente una sentencia). "Hágase, que yo me obligo / de pagar", Cancionero, pág. I6r. "Si tú entiendes de pagar / lo que a otro se debiere / no niegues el te obligar / y prenda o seguro dar" II, p. 703. "El amigo es obligado / en ley de buena amistad, III, p. II3, r. I55. 
al tratar tales asuntos, según ha obserrado ya Margarita Morreale ${ }^{1}$.

En consecuencia, todo lo que se refiere a algún rasgo jurídico queda determinado con un acierto semántico y tecnológico que nos delata. al profesional. Veamos cómo razona Lázaro ante el desastre de la longaniza: "Por ventura lo retuviera mejor mi estómago, que retuvo la longaniza, y, no paresciendo ellas, pudiera negar la demandal) (p. II6); es decir, de no aparecer cuerpo del delito, no hubiera sido viable la demanda criminal. Observemos también la precisión con que se desarrolla toda la escena del embargo de la inexistente hacienda del escudero: los acreedores avisan alguacil y escribano, que proceden a abrir la puerta en presencia de un testigo, pero, al ver la casa desmantelada, creen estar ante un fraude ${ }^{2}$, por 1o que el alguacil intenta prender como cómplice a Lázaro; éste, amedrentado, se dispone a declarar lo poco que sabe y el escribano a preparar su inventario; se expresa la creencia de que por escasa que sea la hacienda del escudero ${ }^{3}$, bastará para

1 "Hasta en la expresión verbal corren paralelos el Lazarillo y las súplicas de los procuradores». Reflejos de la vida española en el "Lazarillon. Clavileño, V, I954, n. 30, pp. 28-3I.

2 En el Entremés de Horozco se menciona el caso de una moza que ha hudo precisamente "con muchas joyas y paños", Cancionero, página I69. Advirtamos que, en el caso del Lazarillo, también se creyó que se habian llevado "sus arcas y paños de pared y alhajas de casa" (púgina 220).

3 En estos casos, el I,icenciado Horozco aconsejaba pcrder lo menos posible $y$ actuar con rapidez. Veamos su comentario del refrán Del mal pagador, siquicra en paja (III, p. 718, r. 674): "Si algún hombre te debiere / lo que no puedes cobrar, / si por caso aconteciere / que algo en pago te diere, / no lo dejes de tomar. / Tomando por su valor / en pago cualquiera alhaja, / es más seguro y mejor, / porque dcl mal pagador, / cobrar y siquiera en pajan. El empleo estilístico de giros y léxico de carácter juridico es, por supuesto, nuy frecuente en Horozco, en quien representan una supervivencia más de la vieja técnica de cancioneros, pues sobreabunda en sus obras de burlas. Como ejemplo podemos citar las coplas que dirigió al doctor Pero Vázquez "porque después de una enfermedad que tuvo cabo el sieso 
responder de la deuda; sobreviene, después, el problema de pagar al alguacil y al escribano, y se expone correctamente la alegación de ambas partes; un porquerón carga con el alfamar y todos se marchan dando voces; Lázaro concluye el relato del incidente y formula su comentario de cómo el infame lecho terminaría por pagar todas las costas.

La relación de las trapacerías del buldero despliega el mismo lujo de precisión jurílica, sobre todo al contar cómo hace caer a los villanos en la trampa cuando finge el regalo de las bulas, con todo su truco de inventariar a los beneficiarios y legalizar doblemente, mediante su propio escribano y el del concejo, el documento comprometedor.

Las deducciones que hasta ahora llevamos hechas nos permiten ir encerrando al autor en un círculo de radio cada vez más corto. Es bastante claro que era un toledano, o persona muy familiarizada con la vida de la ciudad en que escribió su obra, en fecha más bien tardía, sobre mediados del siglo. Con tales antecedentes parece lo más sensato proyectar nuestra investigación sobre los escritores locales y aficionados toledanos de aquellas calendas. Si, además, tencmos en cuenta que, con toda probabilidad, el autor del Lazarillo es un jurista, creemos no se forzará en absoluto la interpretación si consideramos como más probable candidato al único hombre que parece reunir todas esas condiciones previas: el Licenciado Sebastián de Horozco.

\section{REFRANES}

Fué Sebastián de Horozco aficionadísimo a coleccionar refranes, con los que formó el más copioso repertorio de su época, que incluye $-y$ no se conserva completo- 8.3 Ir, de

le quedó una fístola": "Procurá de le cerrar / antes que tome corrida, / que si prosigue en manar, / por servidumbre cular / la ternéis toda la vida", Cancionero, p. ro3. 
lo que estaba muy satisfecho ${ }^{1}$. $\mathrm{Y}$ no contento con superar a todos en cantidad, deseó sobrepasarlos también en calidad, por lo que dedicó a la tarea de glosar 3.I45 refranes muchos ratos que otros dedican a inútiles ocios ${ }^{2}$; la glosa consiste, generalmente, en una doble quintilla en que suele partir del enunciado de un caso concreto para terminar con la inserción, eni los versos finales, del texto del refrán; cuando toca alguno de sus temas favoritos, alarga la glosa hasta explayarse completamente a su gusto, con lo cual llega a formar curiosos poemitas. La colección es hoy conocida sólo en una mínima parte, pues la publicación que inició Cotarelo, y a cuyas puertas se rechazaba la tesis de Cejador, cesó bruscamente al llegar al refrán 8or, sin que en lo sucesivo se hiciera honor al continuará que figuraba al pie de la última serie, ni tengamos la menor noticia sobre los motivos de tan abrupto corte.

Merece la pena meditar un poco sobre el auge de los refranes en nuestro siglo xvr. Influjo erasmista se dirá, y no hay inconveniente en admitirlo, aunque sí es preciso aclarar cómo el erasmismo no venía más que a reforzar en todo caso, y lo mismo que en otros aspectos, una larga y respatable tradición medieval acerca de la que basta recordar la precocidad con que ya. el Marqués de Santillana recogía los refranes que decían, tras el fuego, las viejas de su tiempo. Más interesante aún es el empleo estilístico del refrán, que podemos considerar iniciado en el Arcipreste de Hita ${ }^{3}$ y perpetuado por su colega de Talavera, Santillana, Alvarez Gato, La Celestina, el Lazarillo mismo, hasta llegar a imprimir carácter en el Quijote ${ }^{4}$. Al

1 Su descripción puede verse en Cotarelo, art. cit., p. 693, II · Se conserva en la Biblioteca Nacional bajo la sig. I849 (G-247).

2 "Daterminé, para mi recreación y en ratos y tiempos desocupados de mi estudio $y$ negocios $y$ en tiempos que otros en juegos $y$ cazas y otros exercicios de pasatiempo se ocupany. II, p. 695. Sa trata, por supuesto, del Libro de proverbios o Refranes glosatos. Puede verse su descripción bibliográfica en COTARELo, art. cit., p. 693-694, II.

3 I,EO SrITzER, En torno al arte del Arcipreste de Hita, en Lingïistica e Historia literaria. Madrid, Gredos, I955. pp. I4 I-I42.

4 Es interesante comprobar cómo el interés por el refrán prende 


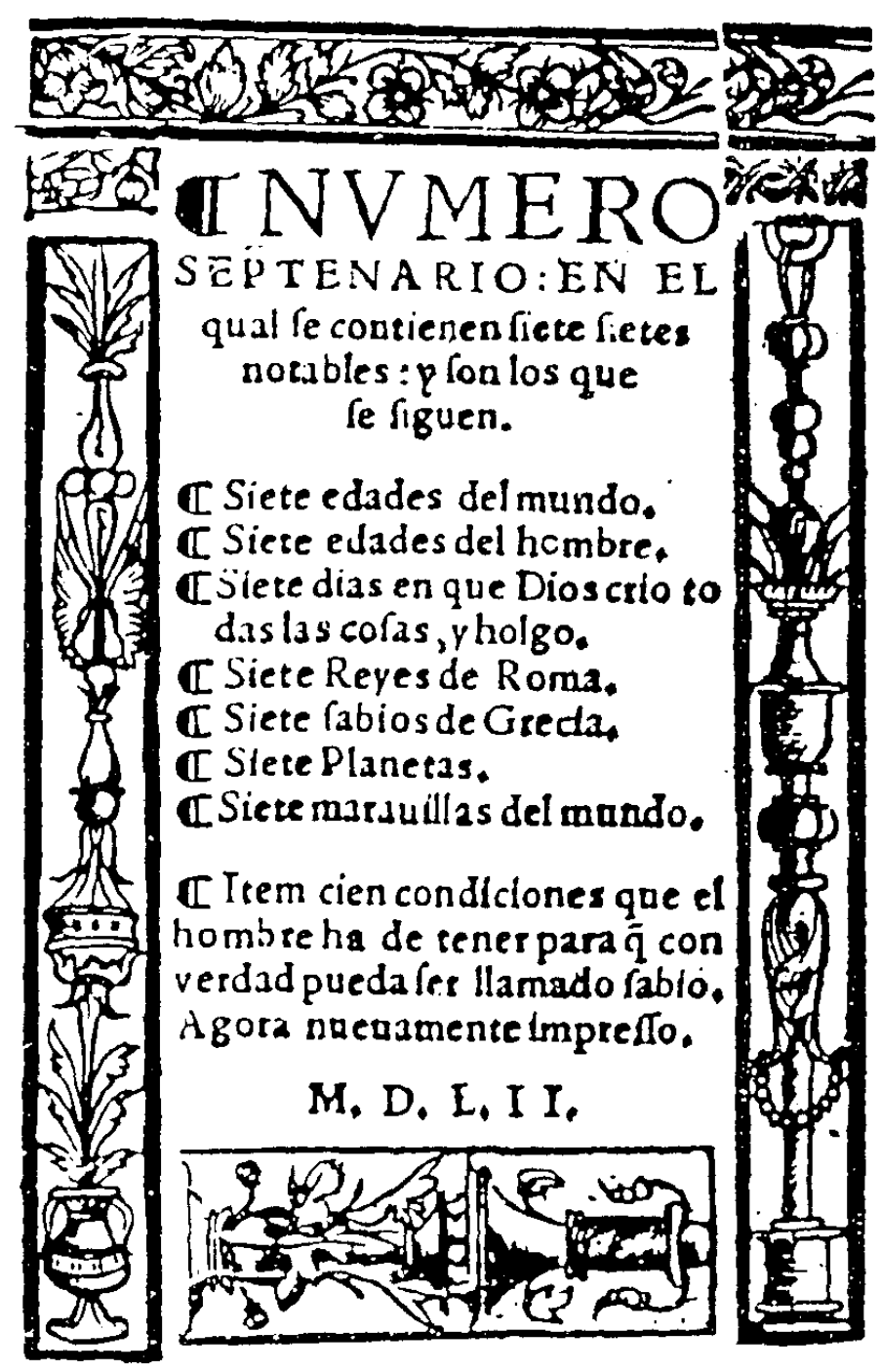

Sabioquien bupcocenojop pafion fabio quicn pienfafu fer q̄ cs moztsl. I Sabio quié bonrra legun å cõulene rabio quien babls a fultempor con fero fabio quien mide fus bablas con pero rabio quien fiempac lo jufto manilicne. IT Sabio quiē guarda la börra a fu br̆o fabioden guardafus propios fentidos fabto quicn ticne oeffeos fubidos rabio quien muere por 108 foberano. II Sabio quien bié oe fup piorimo fiente fabto quien ope/tambien pee $p$ calla rabto quien nunca en los males fe balls Tablo quiten pugna oe fer oiligente.

\section{Ifin. \\ Bo fueimpzeffoel pze. fente tractado en burgos: en cafa oe Juan oe Junta. Zño oe mil equinientos pcinquenta Q 008 años.}

Portada y colofon del Nimero septenario, Bursos, Juin de Junta, i 55 . 
reforzarse esta entrañable tradición con la actualidad erasmista, resultan ciertas las palabras de Marasso ${ }^{1}$ : la colecta de refranes y el arte de glosarlos fue, para aquellos hombres de letras, una tarea casi aledaña del comentario de textos clásicos.

Cabe formular múltiples observaciones acerca del centón de refranes glosados por Horozco. Como ocurre en otros repertorios de la misma época, se recogen toda suerte de dictados tópicos conversacionales, chascarrillos e historias de todas las procedencias y colores ${ }^{2}$, además de las fórmulas propiamente paremiológicas; de ahí nace una impresión de abigarrada variedad que llega casi a marearnos en una primera lectura, pero que constituiría para Horozco el mayor atractivo de aquel pequeño paraíso en que su espíritu travieso se vuelve y revuelve, como bolita de mercurio, en las más insólitas direcciones: de lo devoto a lo chocarrero, de la obscenidad al ascetismo, de lo escatológico a lo didáctico, de la ternura al sarcasmo. Con todo ello vemos situarse a Horozco en esa triple encrucijada en que convergen y divergen la moral, la sátira y el humorismo, ese difícil terreno literario en que nuestros mejores hombres han gustado de plantar sus atalayas para contemplar a la humanidad.

Pero a pesar de encerrar en sí lo divino y lo humano, habido y por haber, también se capta pronto un carácter unitario en la omnipresencia de un cierto espíritu práctico que hace de la colección un inmenso archivo de experiencia vital, rastrera, a veces, pero siempre auténtica, y que no sabemos calificar mejor que llamándola, en suma, algo así como gra-

con extraordinaria pujanza entre escritores vinculados a esa región central que, durante el $\mathrm{xV}$ y el xvi gravitó sobre Toledo.

1 Aspectos del Lazarillo de Tormes, p. 185.

2 "Procurando de cosas tan vulgares y por común peculiar uso en tan poco tenidas, sacar cosas no menos notables que agradables a los lectores, en que hallarán historias, cuentos graciosos y fábulas moralizadas y otras cosas de mucho gusto, allende muchas sencencias y verdades de la Sagrada Escritura". II, p. 605. 
mática parda. Veamos, como botón de muestra, la glosa de $A$ mozo alcucero, amo roncero (III, p. I23, r. 233):

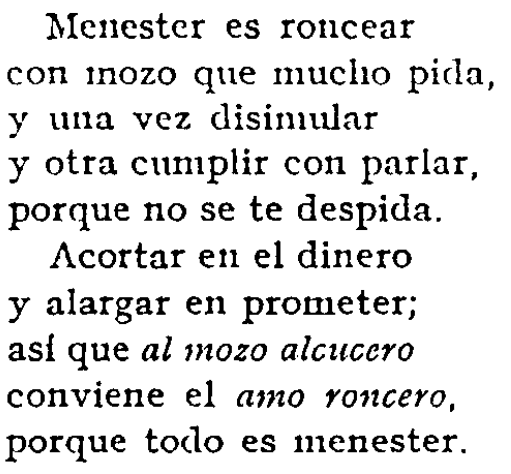

Como veremos, otro atractivo del Libro de Proverbios reside en la naturalidad y casticismo de la versificación, cautivadora por su mismo desaliño y familiaridad, en esa sobrecogedora cercanía al lenguaje hablado que impregna cuanto salió de la pluma de Horozco.

En el Lazarillo hemos de encontrar muchos refranes, enunciados unos y soterrados muchos más, que sirven de norma de conducta a los personajes y en primer lugar a Lázaro, según ha observado también Marasso: "Interiormente Lázaro se guía por el consejo de los refranes; los usa pocas veces, eligiénclolos con eficacia magistral” ${ }^{1}$.

En realidad, todos o casi todos los refranes que aparecen en el Lazarillo se encuentran también en los repertorios de Horozco. El Libro de Proverbios glosa los siguientes: Bien sé de qué pie cojeas (III, p. 4I5, r. 424) aludido por Lázaro en el episodio del escudero: "Y como le sentí de qué pie coxqueaba, dime priessa" (p. I74). Más da el duro que cl desnudo "2; "Arri-

1 Aspectos del Lazarillo de Tormes, pág. i 8. Bataillon considera, con acierto, que la conducta del ciego, que descalabra a lázaro de un jarrazo y después aticnde a su curación, cstá prefigurada por el refrán "después de escalabrado untar el casco" (El sentido del Lazarillo de Tormcs, pág. 17, nota 20). Es casi imposible que Horozco desconociera ese refrán.

2 En número romano nos referimos al tomo de los conservados en la Real Academia, puesto que se trata de refranes a los que no al- 
mávase a este refrán: Más da el duro que el desnudo" (p. I05). La soga tras el caldero (t. II, f. I266-1267), en Lazarillo: "Por no echar la soga tras el caldero, la triste se esforçó y cumplió la sentencia" (p. 86). La simple Recopilación de refranes y ad agios commnes de la Biblioteca Nacional contiene además Tan blanco el ojo (f. 216) y la mención antonomásica Es un Macias enamorado (f. 7) que Lázaro aplica a su señor el escudero cuando se andaba en recuestas con las rebozadas mujeres (p. I85). A veces, el refrán, no enunciado, se transparenta, como en el caso de "lo que uno no come otro se pierde por ello" (p. 7r), en que evidentemente se recuerdan Lo que uno desecha a otro aprovecha (Libro de Proverbios, II, f. I354, r. I630) y Lo que uno no quiere otro lo ruega (II, f. I327, r. I596).

Gracias a los comentarios sabemos perfectamente cómo pensaba Horozco acerca de toda suerte de casos y cosas, con lo cual podemos asomarnos y hurgar en su mundo interior con facilidad ideal. Esta selva de quintillas nos suministran un material dilatadísimo para glosar, a su vez, las fortunas y adversidades de Lázaro. Las semejanzas son, a veces, de un paralelismo asombroso y en otras ocasiones se limitan a enunciar tópicos, temas, conceptos, más o menos similares. Por último, hay también pasajes en los que una palabra, una expresión común, un matiz conceptual nos permiten sorprender el funcionamiento de asociaciones casi subconscientes, muy difíciles de explicar a no ser que hayan partido de un mismo cerebro.

Por eso vamos a emprender un periplo en torno al Lazavillo utilizando como única aguja de marear las coincidencias más visibles - sólo las más visibles, repetimos- que continuamente enlazan los Refranes Glosados, el Cancionero, las Relaciones, con nuestro eterno rompecabezas, El Lazarillo de Tormes.

canzó la publicación por Cotarelo. De toda esta parte inédita sólo hemos podido efectuar una rápida inspección, cuyo abundante fruto asegura abundante cosecha a su estudio detenido. 


\section{CRIADOS Y SEÑORES}

Iîl Licenciado Horozco está siempre muy preocupado por definir cuáles son los mutuos derechos y obligaciones que han de regir la relación humana entre amos y criados. Del contraste con la realidad surge, como siempre, la delación satírica, implacable, de los defectos y llagas que afligen a los distintos sectores del cuerpo social.

Por parte del señor, insiste Horozco, el primer deber consiste en subvenir con relativa amplitud a las necesidades más primarias del criado, sobre todo a su alimentación. En este sentido se expresa al comentar las refranes $A l$ buey que trilla nunca le pongas bozal (III, p. II7, r. I93) y con mayor claridad en el proverbio Al gato, annque sea ladrón, no le eches de tu mesón (III, p. II9, r. 209): incluso las bestias han de estar debidamente alimentadas. Es la norma que violan el ciego y el clérigo de Maqueda, que niegan a Lázaro lo más indispensable para su sustento; el autor lo mira entonces con simpatía, pues no hace sino satisfacerse por las malas de lo que la cicatería de sus amos le niega por las buenas. La idea de una retribución minima y justa del hombre que sirve a otro aflora por doquier en la obra de Horozco. En ella abunda, por ejemplo, Dino es el oficial de su jornal (IV, p. 392, r. 769):

\footnotetext{
Cuando hobiere trabajo en tu hacienda el obrero, justo es que sea pagado, porque va desconsolado, con cansancio y sin dinero.
}

En el mismo sentido se expresa también el Cancionero, sobre todo en su parte dranática. En la Representación de la parábola de Sant Mateo (representada, no lo olvidemos, en I548) y en la Representación de la fainosa historia de Ruth se deleita Horozco en dibujarnos dos figuras ideales de buenos amos: en la primera, es cl Padre de las Compañas, que simbo- 
liza nada menos que al Padre Eterno, y, en la segunda, corresponde el mismo papel a Booz, patriarca llanote y bonachón, que, al contrario que el indigente y puntilloso escudero del Lazarillo, no se enfada cuando sus gañanes le saludan con el igualitario "Manténgaos Dios» o cosa que lo vale ${ }^{1}$. Cuando liace los preparativos de la siega, ordena Booz a su mayordomo:

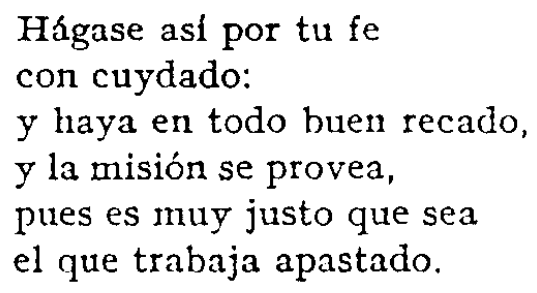

(Cancionero, p. 20I)

Y después obsequia a los trabajadores con una merienda fuera de programa:

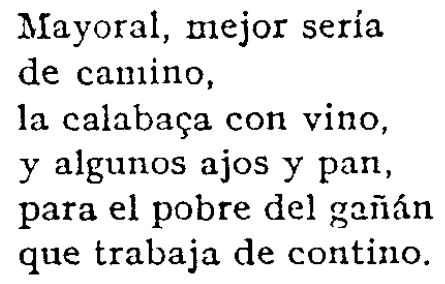

(Cancionero, p. 206)

1 Al verle venir dice uno de sus gañanes: "Oh! Dios guarde / y le mantenga y resguarde, / a nro. amo qu’acá vien» Cancionero, página 206. Y un poco después: $\mathrm{YO}$ buen amo, juro a san, / Dios le tenga / de su mano y remantenga", p. 206. La misma Ruth saludaba asi a los buenos segadores: "Dios mantenga, / mis hermanos" p. 202. Para Horozco, dicha fórmula expresaba el afecto sincero y sin rebuscos de las gentes llanas. También la emplea en la Representación Evanjélica el padre del ciego cuando se presenta ante los incrédulos rabies. Cancionero, p. I64. En cambio, el escudero perdfa los $\epsilon$ stribos con la mención de tal saludo: "Y ansí aquél de mi tierra que me atestava de mantenimiento, nunca más le quise sufrir, ni sufriria, ni sufriré a hombre del mundo, de el rey abaxo, que: "Mranténgaos Dios", me diga" (p.ziz). 
Pero como su ladino mayordomo - un tipo con puntas y ribetes de solemne pícaro- se ha adelantado a sus órdenes, remacha complacido Booz:

Ello está inuy bien ansí.

Que al gañán

nunca falte vino y pan,

entre hombres proveidos, porque los mal mantenidos muy dual trabajar podrán.

(Cancionero, p. 206)

Observemos cómo Booz extrema su liberalidad hasta el punto de of recer vino a sus braceros. También el Padre de las Compañas accede sin inconveniente a la petición que le hace uno de los operarios en el momento de ser contratado:

Pues hanos señor, de dar de beber, que lo avemos menester para alçar bien el açada.

(Cancione'\%o, p. I 52)

Como se ve, la compasión de Horozco por la suerte del hombre que trabaja le lleva hasta este detalle conmovedor de no negarle ese lujo pequeñito de unos sorbos de vino, eterno consuelo del pobre. Así podremos comprender mejor los regocijados afanes de Lázaro para procurarse por cualquier medio su parte en el vino que stus amos no le quieren dar.

Insiste siempre Horozco en los vicios y defectos de los malos amos. Comprueba que "hoy día" es mal general no recompensar debidamente a los servidores, idea que desarrolla en la glosa de $A$ fuer de Aragón, buen servicio y mal galardón (III, p. I02, r. $7 \mathrm{I})$ :

Hoy día cada cual es, en pagar mal a criados, catalán y aragonés: sirvense de ellos, después échanlos sin ser pagados. 
Que es lo que dice también al comentar Arrimaos a ese quejigo (III, p. 404, r. 34I):

Sirviendo toda mi vida a otro por más valer, cosa será desmedida que él sin causa me despida cuando yo le he menester.

Hasta el Lazarillo de la Representación Evanjélica teme que su amo, curado ya de su ceguera, le despida sin pagar «más rezio que una saeta" (Cancionero, p. I63). 'Todo lo cual equivale a condenar procederes como el del clérigo de Maqueda cuando expulsa de su casa al maltratado y doliente Lázaro. Vuelve a insistir en lo mismo la glosa del refrán De servidores leales se hinchen los hospitales (IV, p. 389, r. 746):

Acontece al servidor

$$
\begin{aligned}
& \text { que, por más que sirva y haga } \\
& \text { agradando a su seũor, } \\
& \text { por el menor sinsabor, } \\
& \text { le despide y no le paga. } \\
& \text { Asi que por estos tales } \\
& \text { veréis llenas las paredes: } \\
& \text { De servidores leales } \\
& \text { se hinchen los hospitales } \\
& \text { por servir; jed qué mercedes! }
\end{aligned}
$$

Pero aquí Horozco apunta ya a una nueva diana: el sistema de servicio "a merced", que repudia por ser excesivamente favorable al señor, de forma parecida a como viene a decirlo el escudero: «Ya, quando quieren reformar consciencia y satisfazeros vuestros sudores ${ }^{2}$, soys librados en la re-

1 La mención del sudor para designar el trabajo es lugar común en Horozco. «No sé lo que ha concertado / mi señor / de dalles por su sudor", Cancionero, p. I55. "Y os aplicáis el sudor / y el trabajo rlel letrado", Cancionero, p. 193. "Cierto tiene otro sabor/ lo que de bóbilis viene; / que lo que cuesta sudor, / o dinero o su valor", III, pígina 4I5, r. 428. "Dino es el oficial / de su sudor y jornal", IV, p. 392, r. 769. "No es cosa justa ni reta / que triunfe una alcaguieta / con los 
cámara, en un sudado jubón o rayda capa o sayo" (p. 2I4-2I5). Es curioso cómo esta práctica de recompensar a los criados con ropas usadas, tan común como atestiguan los testamentos de la época, aparece también en Horozco. E1 refrán $A$ ruin mozuclo, ruin capisayuelo (III, p. 404, r. 346):

Al bueno, de terciopelo es poco darle el vestido; mas al vil y ruin mozuelo, también ruin capisayuelo, mientras no lo ha merecido.

Precisamente un sayo de paño era lo que el ciego había dado al Lazarillo de la Representación Evanjélica ${ }^{1}$. En la Parábola de Sant Mateo, unos archipícaros soldados desertores, Picardo ${ }^{2}$ y Rodulfo, deciden sacar partido a la credulidad de las gentes contando una historia lastimosa para obtener limosnas; ante el fracaso del plan, dice Picardo:
No hay quien aya compasión ${ }^{3}$ nuestro ardid ha sido en vano, y será consejo sano dexar aquesta canción no nos den algún jubón.

(Cancionero, p. I5I)

sudores ajenos", III, p. I2I, r. 2I9. "Mas aunque con tal sudor / se vive en cualquier estaclon, III, p. 422, r. 466.

1 "Saquéte de ser picaño / que andabas roto y desnudo, / y dite un sayo de paño», Cancionero, p. I59. Lázaro le responde: «Bien lo trabajo y lo sudon.

2 Un indicio de lo escasamente conocido que todavía es Horozco, lo señala el hecho de no liaber sido utilizado este dato por los partidarios de relacionar con l'icardia y sus harapientos soldados el origen de la palabra picaro.

3 Recordemos la frecuencia con que en el Lazarillo acoge el tema de la poca caridad hacia los pobres. Iázaro mendigaba en Toledo "con harto poco remedio, porque ya la charidad se subió al cielo" (página 166). Cuando hubo de mendigar también para su señor, habla del buen resultado "aunque en este pueblo no avía caridad ni el año fuesse muy abundante" (p. 188). Los toledanos no tenian por lo visto fama de limosneros, según el decir del ciego (p. 105). 
En el Lazarillo, el truhán que adula al ruín justador recibe en premio "el sayete de armas" (p. 73) y el Arcipreste regalaba al complaciente I ázaro las calzas viejas que desechaba.

Pero el espejo implacable de la sátira de Horozco refleja también los defectos de los criados. Se rechaza, en primer lugar, toda suerte de vagancia: mucho mejor es trabajar asalariado que no pasar hambre a pie firme, que es lo que repiten con monotonía todos los trabajadores del Padre de las Compañas en la Parábola de Sant Mateo, tras haber recurrido en vano a la mendicidad viciosa (Picardo y Rollulfo) o a la estafa del prójimo (el mercenario y el echacucrvo). Picardo se expresa entonces con palabras que recuerdan el "tú, vellaco y gallofero eres. Busca, busca un buen amo a quien sirvas" (p. r65) que decían a Lázaro cuando estuvo sano del porrazo que le dió el clérigo:

Pues busquemos un señor con quiell estemos y que nos dé de comer.

(Cancionero, P. I51).

El Padre de las Compañas les reprende su holgazanería:

Por andar ociosos sin trabajar, rio es mucho que no tengáis que comer ni que gastar, mas si os queréis alquilar ganaréis de que comáis.

(Cancionero, p. 151).

Las glosas de Andar a la flor del berro (III, p. I27, r. 267) y Vive y trabaja bien, no habrás menester a alguien (III, p. 4I7, r. 440), vuelven a condenar la holganza una vez más.

También ha de relacionarse con lo anterior el que Enrozco emplee con sentido peyorativo la expresión "ser cual mozo sin señory, que aplica a la beata hipócrita (II, p. 7oI). 
La legislación de las Cortes ${ }^{1}$ nos permite entrever el problema horrible de aquellos niños vagabundos, abandonados por caminos y ciudades de Castilla. En Toledo existían sin duda en gran número, pues muchos upicaños y mozos perdidos que por alli [plaza del Ayuntamiento] se allegaban a jugar” ${ }^{2}$, fueron causa, en 1559 , de un entredicho, que originó, a su vez, una de aquellas tremebundas cuestiones entre autoridades eclesiásticas y civiles, prolijamente historiada por Horozco.

Se insiste, además, en la poca fidelidad de los criados. No llevan otro designio que hartarse y escapar cuando son más necesarios, dice la glosa de Criados son enemigos no excusados (III, p. 7II, r. 625):

\author{
Ninguno tiene ya intento \\ de fielmente servir, \\ sino andar a su contento \\ $y$ tener mantenimiento \\ $y$ al mejor tiempo, huir.
}

Queja en todo consonante con el irónico comentario de Lázaro a la fuga de su amo el escudero: «Pues, señalándose todo lo que podía contra mí, hazía mis negocios tan al revés, que los amos, que suelen ser dexados de los moços, en mí no fuesse ansí, mas que mi amo me dexasse e huyesse de mín (p. 224).

Al lamentar los atentados contra la hacienda heril, adopta Horozco un tono muy cercano, como hemos de ver, a las grandilocuentes y riclículas quejas del clérigo al descubrir la identidad de la perseguida culebra.

Otros refranes muestran la misma repugnancia expresada por el escudero a apegarse al servicio de gente limitada y poco propicia a salir de su paso. Buenos me maten y ruines no me den vidla (III, p. 4I9, r. 453):

1 Véanse los datos reunidos por Mrargarita Morreale, especialmente los relativos a las Cortes de Valladolid en 1548 .

2 Bibl. Nac., ms. 9175, actual Aa-105, f. 2 Io. 
No acostumbres ni acontines tratar con gente apocada, que mientras tratas con ruines, por más que a ello te inclines nunca puedes ganar nada.

Que a los que a ruines se abaten la honra tienen perdida, $y$, por mejor que me traten, quiero que buenos me maten $y$ ruines no me den vida.

$\mathrm{Y}$ también recuerda el lenguaje del escudero ${ }^{1}$ la glosa a De ruin montecillo bueno es un gazapillo (IV, p. 387, r. 730):

De quien no sabe hacer mercedes a cada paso, no es poco poder haber cualquiera cosa, por ser de un hombre corto $y$ escaso.

Michos otros temas secundarios podriamos agrupar aquí si el sentido de la medida no nos pidiera pasar a otro capítulo. De todas formas, hemos de volver a referimos en muchas ocasiones a esta materia, que preocupaba a Horozco hasta un grado casi obsesivo.

\section{HAMBRE}

El tema de criados y señores, amalgamado con una espepecie de presencia cósmica del hambre, constituye uno de los pilares básicos del planteamiento literario del Lazarillo. Y

1 "Canónigos y señores de la yglesia, muchos hallo; mas es gente tan limitada, que no los sacarán de su paso todo el numdo. Cavalleros de media talla también me ruegan; mas servir con éstos es gran trabajo. Porque de hombre os avéys de convertir en malilla, y, si no, "Andá con Dios», os dizen. Y las más vezes son los pagamentos a largos plazos y las más y las más ciertas comido por servido" (pp. 213214). En cuanto a la expresión sacar de paso, es frecuente en Horozco: "Y cuando con su trotar / a otro de paso saca" III, p. Ior, r. 63. "Hombres hay tan encogidos, / que de su paso sacados...", III, pígina 403, r. 337 . 
precisamente toda la obra de Sebastián de Horozco se halla empapada de metáforas y dicharachos enlazados a tal azote de la humanidad. Imposible también agotar con mucho semejante filón: nos limitamos a entresacar alguno de los pasajes más representativos o coincidentes.

'Iodo el primitivo armazón de la Parábola de Sant Mateo se reduce a presentar tres variaciones, bastante monocordes, sobre el tema de las lamentaciones de los infelices desmayados que se alquilan para trabajar en la viña del Padre de las Compañas, esquema al que se superpone, como epílogo, un cuadro en el que se exhibe la alegría del remediado en su necesidad por una retribución justa. La dura realidad de los que luchan, cada día, con el problema del hambre, impresionó a Horozco en todo momento. Es la actitud que el Viejo echa en cara a su hijo, el bobo Antón:

Toda tu cuita y trabajo

es por comer.

(Cancioncro, p. 154)

Si hemos de dar crédito a ciertas composiciones petitorias incluídas en el Cancionero, no debió de andar siempre muy abundante la despensa del propio Horozco, que confiesa deber "no sé quántos panes" (Cancionero, p. 97). Algunas de las coplas más pintorescas de todo el Cancionero se dedican a narrar, con deleitación morosa, la aperreada hambre pupilar del triste del estudiante en Salamanca, horca caudina por la que necesariamente hubo de pasar nuestro Licenciado. La descripción de la dieta que éste mantiene durante una enfermedad presenta varias palabras comunes con el régimen de Lázaro en casa del clérigo:

Comiendo de almendra y pasa

no. todo lo necesario,

una ración bien escasa

con toda medida y tasa,

$y$ así pasé el trcintanario.

(Cancionero, p. 83) 
Los mozos malos son siempre golosos y comilones, como enseña la glosa de Al mozo malo, ponelde la mesa y eivialde al mandado (III, p. I09, r. I29):

$$
\begin{aligned}
& \text { Al mozo malo y astroso, } \\
& \text { cuando algo ha de hacer, } \\
& \text { no terná mucho reposo } \\
& \text { ni será muy perezoso } \\
& \text { si ha de volver a comer. }
\end{aligned}
$$

Los ruines se caracterizan, como Lázaro, por su afán de "henchir los senos»:

Los ruines hinchen los senos, siempre mejorados van.

(III, p. II 3, r. I6o.)

Expresión que vuelve a aparecer en el refrán 362 (III, p. 407):

El que es católico y bueno

no procura de adquirir

lo mal ganado ni ajeno, ni de ello henchir su seno sabiendo que ba de morir.

E1 hombre bueno, en cambio, no consigue lo más indispensable, afirma la glosa de Andar a pie con bola; andar a alcanza, no llega (III, p. I30, r. 287):

El hombre que ha de vivir

de su trabajo y afán, no puede mucho adquirir, ni de laceria salir ni tener sobrado un pan.

El problema alimenticio se condensa, para Horozco, en la mención tópica del pan. Este es el mejor alimento, y toda suerte de exigencias y precauciones respecto a su calidad han de ser pocas, nos dice cuando glosa Bocado de mal pan ni lo comas ni lo des a tu can (III, p. 4I8, r. 445): 
El pan es el alimento mís común y necesario que nos da mantenimiento, y ha de ser muy a contento, por ser lo más ordinario.

$\mathrm{Y}$ por esto, de mal pan, no debes couner bocado, ni menos darlo a tu can, si no entonces te dirán que eres malaventurado.

Desde tal punto de vista, se explica uno muy bien los formularios escrúpulos del escudero al informarse de si el pan, que su criado tuvo tantas horas en la sucia arca del seno, era de limpias manos amasado. Pero aún surge más clara una relación con el episodio del clérigo, quien, totalmente limpio de caridad, hace comer a Lázaro el pan que cree ratonado, añadiendo además una apostilla, digna de incorporarse a la antología del humorismo universal, con el pérfido "cómete esso, que el ratón cosa limpia es» (p. I48); máxime cuanto que al clérigo se le califica precisamente de umalaventurado mezqui110" (p. I97). Estamos en condiciones de aprcciar que los refranes pudieron servir al autor como disparadores de temas que formula en su novelita con la mayor eficacia. Notemos también que de esta forma muchos pasajes debieron tener para los contemporáneos, que conocían todo este refranero, un relieve especialísimo que ahora empezamos a vislumbrar.

Por lo demás, al pobre no hay quien le dé un pan (III, p. II7, r. I 88), que se niega al hombre más noble y no se tasa a rameras y truhanes (III, p. I2I, r. 2I9). El procurador sin clientes ni escrúpulos de la Rcpresentación Evanjélica se queja también de que no alcanza un pan (Cancionero, p. I6o), y lo mismo se afirma de la legión de parásitos y catarriberas que cayeron sobre 'Toledo al establecerse alli la corte en I560 ( Cancioncro, p. 184). Unos bocados de pan bastan al pobre para estar sano y colorado (III, p. 4I3, r. 4I2). A la hambre no hay mal pan-ipobre escudero!- (III, p. I05, r. 96), Al pan duro, dicnte agudo - iay, soñado pan de cuatro libras!- (III, p. I3I, 
r. 297), pues Alque bicn le sabe el pan, por dcmás salsa li dan (III, p. Iog, r. I23), y estamos ante una conexión hanbre-salsa que aparece por dos veces en el Lazarillo ${ }^{2}$. Ifl trabajo humano se endereza exclusivamente a procurar el sustento, $y$ toda esta serie temática podemos considerarla rematada en el borbotón histérico del obrero de la viña al recibir su salario:

Si más que no, Dios loado, ya tenemos para pan.

(Cancioncro, p. 156).

Pero también insiste Horozco en la idea de que una alimentación excesiva resulta perjudicial, idea tan cara para sus amos como aborrecida de Lázaro. Varias veces lanza el Licenciado sus filípicas contra amigos destemplados en comer, como aquel Licenciado Montareo, que, en vez de tomar las píldoras prescritas para su dolencia, se fué a Pantoja, cl muy bárbaro, "para hartarse de menudos de puerco»:

Diz q'os fuistes a hartar

de tripas del cagalar

de los puercos de Pantoja.

(Cancionero, p. 53 ).

O contra el predicador Fr. Antonio Navarro, que por poco muere a causa de haberse dado un hartazgo de empanada de salmón durante una convalecencia (Cancionero, p. 250).

Hay todo un interesante grupo de refranes cuyas glosas desarrollan una condena de la intemperancia, fundamentada en el acortamiento de la vida que ésta producc. Así, Comc poco y cena más (III, p. 598, r. 562):

Porque si relleno estás, mil veces enfermarás, por do vengas a morir.

1 "Puesto caso que yo no avía menester muchas salsas para :omer" (p. I 54). "Con mejor salsa lo comes tú", piensa Lázaro cuando su hambriento amo elogia el almodrote (p. 193). 
Comer y beber echan al hombre a perder (III. p, 597, r. 560) y más aún De hombre reglado, médico no habrá cornado (III, p.719, r. 684):

Claro está que más priado cnferma el hombre glotón.

También la glosa a Después de comer, dormir; después de cenar, bullir (IV, p. 388, r. 74I) contiene "reglas de regimiento" alusivas a las comidas, lo mismo que Comer hasta enfermar $y$ aymar hasta sanar (III, p. 597 , r. 555), que también recoge "reglas de medicina". Como se advierte, todo esto es lo que condensan las engoladas excusas del escudero, en su aVivirás más y más sano... Porque, como dezíamos oy, no ay tal cosa en el mundo para vivir mucho, que comer pocon (p. I77), o en su lapidaria sentencia "porque el hartar es de los puercos y $\in 1$ comer regladamente es de los hombres de bien» (p. I72). Digna de especial atención nos parece la coincidencia de la palabra regla y clerivadas, que tanto Horozco como el autor del Lazarillo adscriben a la fórmula de tópicos similares. Horozco:

En regla de regimiento oygo dezir de contino ser dañoso bastimento y muy mal mantenimiento el de los higos y vino.

(Cancionero, p. 20)

Lázaro: "Que siempre he guardado essa regla por fuerça y aun espero por mi desclicha tenella toda mi vida» (p. I77).

Establece nuestro Licenciado cómo cada uno debe comer de acuerdo con su condición, su «estado» ${ }^{1}$. Según la glosa de

1 "Diversos son los estados / en este mundo de gente», III, página 425, r. 485. "Que el estado que posees / es tuyo que lo has ganado", IV, p. 395, n. 739. "En querer andar en coches / por hazer inás del estado", Cancionero, p. 245. "Y tatnbién porque consideren los que heredaron nobles estados quán poco se les deve", Lazarillo, p. 75. Lil me dio industria para llegar al estado que aora estón, p. 257. 
Al villano, puerro y ajo, y no manjar blanico (III, p. I In, r. 20.3), el gañán ha de alimentarse de cebollas y tasajos, mientras que los delicados comerán faisán y otras lindezas por cl stilo. A pan y cebolleta no cumple tañer trompeta (III, p. I32, r. 3or) y la glosa de Cásate, hijo, y comercís cabeza de olla (III, 1). 594, r. 537) insisten en presentar el pan y la cebolla como tópico - todavía hoy vulgar - del más ruin de los alimentos, y que es precisamente lo que da de comer a Lázaro, con cuentagotas, el más odioso de sus amos. Como tópico de la comila o manjar más excelente, hemos visto ya que se hace referencia al faisán:

Hay unos hombres glotones, epicúreos, holgazanes, que sus misas y sermones son comer buenos capones Y aun, cuando pueden, faisanes.

(III, p. + I9, r. $45^{6)}$.

Una revisión de la parte inédita de los Refranes Glosalos ofrece nuevos datos sobre la oposición conceptual pan-faisán; el Igor enuncia precisamente Más quiero en mi casa pan que en la ajena faisán (f. ${ }^{\circ}$ I.489, t. II) y el r.869 Más vale pan duro que pera [o] higo maluro, tras alabar las cualidades del pan:

La gallina y el capón el perdigón y el faisán, el francolin y el pavón, La tórtola y el pichón poco valen sin el pan.

$(F .15+5-15+9$, t. II $)$

E1 escudero, cuando devora las tripas que le ha traido Lázaro, no lo hace por hambre sino porque "n1o ay faysán, que ansi me sepa" (p. I92). 


\section{GENIO Y FIGURA DE LAZARO}

Abundan en Horozco los pasajes que nos recuerdan casi todo lo que Lázaro hace, dice o piensa a través de su lastimoso y divertido relato. La relación a veces es muy clara, como en el caso del refrán Dios, cuando da la llaga, luego da la medicina (IV, p. 393, r. 777) o de su variante Dios por un cabo castiga $y$ por otro medicina (IV, p. 394, r. 784) que Lázaro amplifica levemente: "Bendito seáys vos, Señor, quedé yo diziendo, que dáys 1 a enfermedad y ponéys el temedio!n (p. I8I-I82). Aunque lo más común es, por supuesto, el hallazgo de temas y tópicos orientados en la misma dirección.

$\mathrm{Y}$ así podemos comenzar señalando la actitud de Lázaro al contar con pelos y señales la poco edificante crónica particular de sus progenitores, rasgo que aceptará en bloque toda la picaresca posterior y donde no hemos de ver sino un aspecto más del tema del determinismo de la sangre, mito oficial de la época. Pues bien, la creencia de que el hijo será fundamentalmente igual a sus padres aparece infinidad de ocasiones en Horozco. A la hija de la puta, su madre le saca de culpa (III, p. I09, r. I24), con la notoria afinidad al «no saldría peor hombre que mi padre" (p. 88) de la recomendación al ciego. Al hijo del gavilán nunca le falta caza (III, p. II5, r. I75), De casta le viene al galgo tener el rabo largo (III, p. 720, r. 692), ¿De dónde saltó esta astilla? De aquel mal madero (IV, p. 383 , r. 703), De ruin cepa ruin sarmiento:

El que viene de ruin gente siempre vuelve al fundamento, $y$ es ruin $y$ de ruin simiente, como sale comúnmente de ruin cepa, ruin sarmiento.

(IV, p. $3^{86, \text { r. } 727)}$

De gran interés resultan para nosotros las variantes del mismo refrán en que la idea se extiende a señores y criados: Al son que me hicieres, a ése bailaré (III, p. II3, r.I59): 
Los hijos y servidores hacen lo mismo que ven a sus padres y señores, y les llevan los tenores siguiendo su mal o bien.

Y lo mismo Al mal abad, mal monacillo (III, p. I23, r. 235):

El malo procura y cría otros tales servidores.

Donde surge la alusión al mal monaguillo, uno de los oficios de Lázaro y que todavía hoy conserva halo y tufo picaresco en los dichos del vulgo. Muy parecido el 250, A mal capellán, peor sacristán (III, p. I25 r. 250).

La historia desastrosa de la madre de Lázaro y el caballerizo negro pudo muy bien reflejar algo que debió suceder no pocas veces en los medios en que vivió Horozco, quien nos habla, alguna vez, de los negros y negrillos de '́loledo ${ }^{1}$. A tuna dama que vivia deshonestamente le echa en cara que numca cerró su posada "a ningún negro ni blanco» (Cancionero, p. 29). Y a pesar de todo, un agudo comentarista del Lazarillo ${ }^{2}$ ha señalado ya cómo, por encima de la desfachatez cle Lázaro para infamar a sus progenitores, la figura de la madre ha sido tratada con una sobria terntra que sale a flote en la punzante escena de la despedida. Incluso al describir su la-

1 "X detrás un carro triunfal con el tiempo, que era un vicjo calvo con una guadaña en la mano y un niño, y en el mismo carto yvan unos negrillos dançando y haziendo inonerías". "Viernes XXIII dias del dicho mes ovo una máxcara de negros, todos a la gineta y con buenas libreas en que yvan doze, y al cabo un carro triunfal con una rreyna negra con un gato paus en los braços, y ciertos negrillos, delante della el negro dios de amor que era un negrillo enqueros vendada la cara y con su arco". Cedru, To, Tolo en el siglo XVI, ap. VIII: "Fiestas y alegrias en Toledo con motivo del nacimiento de la Infanta D. "Isabel Clara Eugenia (I 566)", p. 201 y 202.

2 Minuel Muñoz Cortés, Personalidad y contomo en la figura del Lazarillo. Escorial, X, 1943, p. II4. 
mentable vida de prostitucion, se parte, sin embargo, de un dato previo que en el despiadado ambiente del Lazarillo equivale casi a justificarla: "NIi biuda madre, como sin marido y sin abrigo se viesse" (1). So). También expresa más de una vez Horozco cómo el abandono y la miseria surten malos efectos sobre la castidad femenina: A la milu, pobreza le hace hacer vileza (III, p. II5, r. I78), cuya glosa aclara que, aunque 110 exima de responsabiliclad, la experiencia comprueba lo verídico del proverbio. En otra ocasión vualve a expresar cierta simpatía lacia "la pobre mujer [que] usar mal de sí comienza» (III, p. 596, r. 547). Como vemos, dista mucho Horozco de ser un mero versificador chocarrero, de los muchos que sobraban en su época; su mundo de sarcasmos y desenfados de toda índole tiene también sus rinconcillos para la floración de una exquisita y melancólica delicadeza de sentimientos.

Cree nuestro Licenciado, asimismo, que los defectos del niño no harán sino aumentar con la edad, según se expresa cuando comenta De becerrillo veris qué boyezilelo harás (III, p. 720, r. 689), De mal cn peor (IV, p. 384, r. 708), Del hillo al pabilo, del pabilo a la mazorca, de la mazorca a la horca (III, p. 7 I 7, r. 67I), peculiarmente diguo de atención por presentar una profecía de la horca que no es única en la obra de Horozco y que coincide con un pasaje del Lazarillo de autenticidad muy controvertida ${ }^{1}$.

Por lo demás, Lazarillo, niño precoz, avispaclo y listo,

1 No es éste lugar de plantear el problema de las adiciones del Lazarillo de Alcalá. Por el contrario, son tales pormenores los que poclrán orientarnos para su enfoque y resolución. La profecia de la lorca se encuentra cn el Cancioncro: "El auctor burlando de uno que dezia que no se habia de casar sino con una viuda y rica, le dize de una, entendiendo por la horca" (p. 7). La profecia de malas cenas, contenida en el mismo pasaje $y$ alusiva a su futura vida matrimonial, aparece también en Horozco como tópico de preocupación y sinvivir. El lechuzo de la Representación Evanjélica dice concretanente: "Y por lo que sucediere / al sentenciar / no dexaré de cenar / ni dormir por ninguna arten, Cancionero, p. 7, I60. A lo mismo se refiere el fraile contento del Cancionero, p. 274. 
después de ganarse - cheque en blanco- nuestra simpatía, nos defrauda escandalosamente al llegar a la edad adulta conrertido en un ser abyecto. Un refrán de Lorozco también nulestra poco entusiasno por la excesiva precocidarl de los niños: Zancas aanas, luego espigas y tarde granas (III, p. 59I, r. 5 I6). Lo mismo viene a clecir Arbol que temprano echa, tarle lleva su cosecha (III, p. 404, r. 344) ${ }^{1}$.

Quizás resulte tarea premiosa la de anotar otros múltiples puntos de contacto, pero aún homos de comentar algunos. Jin primer término, la actitud de Lázaro respecto a la cicatería de sus amos, su reacción ante los abusos de que se ve objeto". Varias glosas aconsejan no ceder y hasta adelantarse al mal designio del prójimo, norma elemental de la gramática parda de todos los tiempos. Asi la de $A$ un min, min y medio (III, r. 378, p. 409 ):

Con el que quicre tratar
contigo de villania,
bien te puedes antuviar
y de la cautela usar.
que contra ti comeda.

Auténtica regla de oro del constante contraminar de IázaIo, y que repiten, poco más o menos, los refranes $A$ untraidor, dos alevosos (III, p. 4IO, r. 390), Conter con él y guarte de él (III, p. 597, r. 556), A quien te quiere matar, madruga y muitalo (III, p. 399, r. 3IO).

Los temores de Lázaro a cambiar de amo están igualmente

1 Lna curiosa variante de estos refrancs conservan los judios marroquies: El hijo del judio al mes anda, y al año gatea. Josli IBENoInEL, Dialccto judeo-hispano marroqui o hukitia, BIAL, XIV, I927, página 216.

2 Estudiada y puesta muy de relieve por HonIro CASTIIIO en El comportamicnto de Lazaro de Tormes. Hispania, California. XXXII, 1950, págs. 304-3 ro. Aunque se formulan aqui atinarlisimas reflexiones sobre la existencia en Irázaro de tuna personalidad noral sui gencris, no cabe en absoluto accptar la interpretación inoccnte del cpisodio del arcipreste. 
justificados por las glosas de Bien se está San Pedro en Roma (III, p. 4I4, r. 4I7), De rocin a roin, Martin Martin, caila dia más ruin (IV, p. 386, r. 726), y sobre todo por didóncle iremos que más valgamos? (III, p. Ior, r. 59):

Trabajos no han de faitar doquiera que el hombre vaya.

Por ello hay que quedarse donde pueda haber siquiera una felicidad material y chiquita, a la que Lázaro demostrará estar dispuesto a sacrificar hasta lo más sagrado:

Dondequiera que hallamos buen albergue $y$ acogida, alli nos arregostanios, acogemos y albcrgamos, no habiendo quien nos lo impida.

$\mathrm{Y}$ donde nos dan pan tierno, buena cama y buena brasa, vámonos a buen gobierno. conno el puerco y aun al yerno mostrada una vez la casa.

(III, p. I I0, r. I 32)

Otros detalles se esclarecen por la misma vía. La compasión de la tripera, que dió a Lázaro su pobre socorro, es también el tema de un vejamen burlesco (Cancionero, p. 56) para uno que se había de doctorar in utroque y cuyo estómago agradecido le llevaba a prometer casarse con su benévola protectora.

La pequeñez misma de dormir Lázaro a los pies de la cama de su señor el escudero aparece igualmente en la Representación de la famosa historia de Ruth:

Acostarte has a sus pics, debaxo de la cobija.

(Cancioncro, p. 205)

Y también en una de las composiciones más subidas de 
color que hay en todo el Cancionero (p. 98), en que se dice lo mismo de una criada y su amo ${ }^{1}$.

Hemos aún de referirnos al oficio de pregonero, que Lázaro elige para llegar a la cumbre de su buena fortuna. Este pregonero de 'Toledo es también uno de los protagonistas de ese terrible Entremés, que Horozco nos asegura que hasta se representó y todo ${ }^{2}$, pensado para infamar la figura de un fraile callejero, ignorante y glotón; introduce a éste en la buena compañía del pregonero de Toledo, un villano y un buñolero con los que se entrega a toda suerte de burlas y chocarrerías; resulta muy clara la intención de rodear al fraile de la gente más soez. E1 oficio de pregonero estaba aureolado, al parecer, de la peor fama y no en vano el Pelegrino curioso lo califica de "el oficio más infame que hay» ${ }^{3}$, en lo que no influi-

1 En este caso concreto es posible que estemos ante un recucrio de La Lozana andaluza, que permitía semejante familiaridad a su criado, el indeseable Rampin, que hacia de ella el uso que cabe imaginarse.

2 "Siguese un entremés que hizo el auctor a ruego de una monja parienta suya evangelista para representarse cono se representó en un monasterio de esta cibdad dia de Sant Ju. Evangelista" (Cancionero, p. 167). Hasta la rúbrica parece que se complace maliciosamente al asegurarnos que llegó a ponerse en escena. En efecto, jamás fué Horozco más allá en el tema de la sátira frailuna, ni es probable que ésta haya sido nunca sobrepasada en ferocidad.

3 F. DE HAAN, Picaros y ganapanes, en Homenaje a Menéndez Pelayo, II, Madrid, I899, págs. I85-I86. Recoge la misma insinuación un refrán del libro de HERNíN NúNEZ: "En linages luengos, alcaldes y pregoneros». Refranes o proverbios que nuevamente colligió y glossó el Comendador, Hernán Niiñez. Salamanca, Juan de Canova, $1555,{ }^{\circ}{ }_{4} 6 \mathrm{r}$. En las feroces sátiras de Gómez Manrique contra Juan Poeta, hay algún fragmento que parece de encargo para Liazaro: "Mas yo creo que su padre/sabe más del pregonar/ lo que se suele perder, / y la puta de su madre/de los modos del andar/que el fijo del componern. R. Fourchís-Delbosc, Cancionero castellano del siglo XV. Madrid, r9 I5, volumen II, página Iro. Otros ejemplos permiten apreciar que éste era el linaje que en los cancioneros encerraba el tópico de la infania más extrema. Y Holozco es uno de los últimos poetas que siguen esa corriente literaria. 
ria poco su proximidad al de verdugo, a quien el propio Lázaro acompañaba con excesiva frecuencia. Más aún, ese pregonero toledano del Entrcmés sale a escena echando un pregón para encontrar cosas perdidas: una muchacha que se ha escapado con las alhajas de la casa (Cancionero, p. I69). En el mismo Cancionero cuenta Horozco haber visto pregonar en subasta un cuero de vino (p. I2I), y en otra composición se recuerda a cierta dama que está prohibido vender vino sin pregonarlo primero (p. 24), lo que explica muy bien que ésta fuera precisamente la primera actividad pregoneril de Lázaro y la que le permitió entrar en tan buena amistad con el Arcipreste de San Salvador. No puede pedirse mayor acuerdo con el oficio de Iázaro: "Y es que tengo cargo de pregonar los vinos, que en esta ciudad se venden, y en almonedas y cosas perdidas, acompañar los que padecen persecuciones por justicia y declarar a bozes sus delictos: pregonero, hablando en buen romance) (p. 256).

\section{EI, CII:GO}

Los ciegos cruzan a través de los versos de Horozco, que había observado el tono destemplado y gesticulante en que recitaban sus oraciones milagreras:

\footnotetext{
$Y$ es lo que señor, os ruego por onra de la poesía, que tengáis algún sosicgo, y no os déis a todos luego alçando el tono a porfía como de oración de ciego.
}

(Cancionerc, p. 220)

Según dice el Cancionero a un versificador novel. Por el contrario, el amo de Íázaro rezaba en un tono bajo, reposado y sonable, sin hacer gestos ni visajes con boca ni ojos, como 
era costumbre en quienes no eran, como él, águilas en el oficio ${ }^{1}$.

Lázaro recibe del ciego avisos para vivir, más valiosos que el oro y la plata que su ano no puede darle, concepto que expone Horozco al glosar Corregïela de buen cuero, de lial mozo hace bleno (III, P. TIO, T. 6r5):

Quien hijos ha de criar, conviene mucho que enticnda en saberios castigar; que no les puede dejar mejor renta ni hacienda.

Más le valdrá que dinero ponter a sus males freno, y aunque les duela el trasero, corregücla de buen cuero, de mal mozo hace bueno.

Punto de vista que nos justifica al mismo tiempo esc "Castigaldo, castigaldo, que de Dios lo avréys) (p. I0.3) con que las gentes azuzaban al cicgo contra el desclichado Iázaro. Igual

1 La semejauza del pasaje citado fué advertida por CrjADOR (página 4I) y negada por Co'rAREro en estos térmiuos: "Iid Lazarill" dice que los ciegos hacian "gestos y visajes con boca y ojos" y $\mathrm{cl} \mathrm{C}(1)$ cionero que alzaban la voz, cosas muy diferentes para que pueda diccirse que uno innitó a otro" (II, p. 684, nota). En realiclad, cualquiera puede apreciar que ambos pasajes derivan de nna misma experiencia. pues se refieren a la exagerada y ridictua manera en que lecían los ciegos sus oraciones. Se calló Cotarelo que unas líneas antes alude el Lazarillo a la cadencia agradable y devota del recitativo del amo de Lázaro. Nos detenenios en este detalle para destacar un ejemplo típico del superficial parti pris con que procede la critica de Cotarclo. Recicntemente liemos sabido, a través de un excelente estudio de I:vci:Nio Asfrnsio, que el libro de Fir. Francisco de Evia, Itineratio to la Oración, al combatir las supersticiones de la ćpoca "recuerda" las oracionrs que rezan los ciegos, hechas en coplas, donde van mil disparates" y los que por no poder aprenclerlas, los alquilan para que las recen en su nowbre». Casi produce escalofrío pensar que el libro de Livia se imprimió ien 1553 ! El crasmismo y las corrientes espiritudes afines $R F E$, t. XXXVI, I@52, p. 96. 
viene a decir la glosa de Al cnhornar se hacen los panes tuertos (III, p. II3, r. I56):

Castigar es menester.

los mochachos cuando chicos.

Y Al hijo más anado, del pan y del palo (III, p. 2I I, r. I46).

También es posible comprobar nua significativa repetición expresiva. Reconoce Lázaro que había momentos en que el ciego le halagaba y trataba bien, sin conseguir, ni por esas, hacerle olvidar las anteriores fechorías: «Y, aunque me quería y regalava y me curava, bien vi que se avía holgado del cruel castigo" (p. I02). Un fraile contento de su profesión se alegra, al dialogar con su eco, de haberse librado de los siusabores que producen los hijos:

-Y qué agonia y cuiclado trae el triste padre muriendo por que su hijo s@a el más rico, mas notado y más visto. Eco. - Has visto.

-Y si algo le cluele, cóuno le regala y cómo lo cura. Eco. - Locura.

(Cancionero, p. 273)

I a coincidencia adquiere todo su valor si tenemos en cuenta que Lázaro había sido aceptado por el ciego «no por moço, sino por hijo') (p. 88).

La habilidad del ciego para recetar con desenvoltura toda suerte de remedios para males más o menos inconfesables, recuerda bastante el privilegio concedido a los bubosos cofrades de la "cofradía del grillimón»:

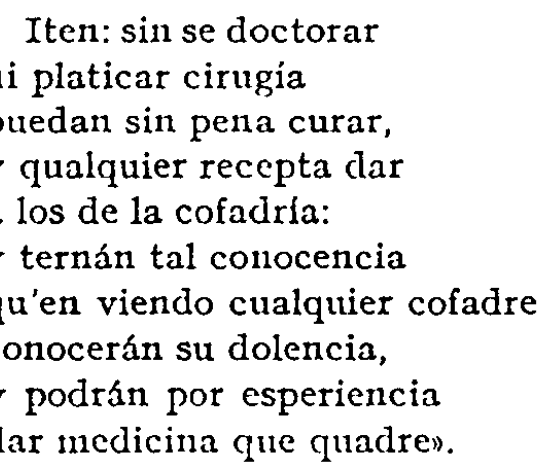

(Cancionero, p. 3) 
Por lo demás, nos hallamos claranente cn un terreno ide resonancias literarias, aunque resulta difícil concretar si las habilidades médicas del ciego derivan de La Lozana o incluso del Corbacho ${ }^{1}$.

Alguna de las trastadas que Lázaro hace al cicgo puede ser rastreada en Horozco. El lance de la longaniza parece aplicación práctica del refrán Comer ura y gormar racimo (III, p. 597, r. 557), cuya glosa insiste, además, en que lo mal ganado viche siempre a pagarse con creces.

Según se deduce de uno de los anteriores apartados, era el vino una largueza que el buen amo no debía negar a su criado; con lo que Lázaro queda justificado si se lo busca como puede. Hasta el I,azarillo de la Represcntación Eianjelica se queja de no catarlo:

1 También la I,ozana sabía toda suerte de merlicina secreta, con mención especial de los males de madre (Manotreto XI.II, p. 2 $1(i-217)$ y pronosticar el sexo de las criaturas por nacer; más arlelante (Nranotreto IXIII, p. 3I7) da una impresionante receta para la esterilidar! femenina, siendo muy de notar que en el Cancionero hay unas coplas (página 29) que versan sobre el mismo tema y los bibliófilos andaluces redujeron a líncas de puntos en su mayor parte. I’or lo denús, puede que también coincida aqui algún eco del viejo Corbacho, en cl que figura el siguiente párrafo: «Sy a ellos llegan quéxanse mucho como mugeres, anortéçense como fenbras. Trabaxan mucho por las virtudes de las yervas por dar a las mugeres melezinas: a algunas para empreñar, a otras para sanar de la madre, del estómago, de la teta, del alfombra, de los paños a las preñadas, de la cara; $d$ dolor del axaqueca, de yjada, del dolor del ombligo, e dende ayuso. Titca. Tocla fysica saben; todo dolor curan; todo mal remediann. Eid. M. PJNNA, Torino, Rosenberg-Sellier, pág. I 88. Interesa notar que el Corbucho hubo de ser muy leido todavia durante la primera mitad del Xr. como demuestran sus múltiples ediciones: Toledo, I518; Logroño, 1529; Sevilla, 1547. Sin que podamos detenernos en este punto, creemos indudable que Horozco conocía el libro del Arcipreste de Talavera, sin el cual es muy posible que el Lazarillo no se hubicra escrito nunca. Desde luego, hay que suscribir la genial intuición de MrinisDEZ Pelayo al afimar que el Corbacho ues el primer libro español en prosa picaresca: La Celéstina y el Lazarillo de Tormes están en gerwen en ély. Origenes de la nowela, Santander, roł3, t. I, pág. I 8 I. 
$Y$ aun en torlo hoy no he bebido sino sólo un escamocho.

(Cancioncro, P. I58)

Añalamos que Horozco lo consitlera además elemento inseparable de una buena comida, según enseñan los refranes Comer poco y remojallo bicn (III, 1. 598, r. 566) y sobre torio Comer y no bebcr, cegar y no ver (III, p. 597, r. 558):

En una comida o cena seria muy gran desatino que estando la mesa llena de mucha vianda, y buena, no hobiese gota de vino.

Lo principal ha de ser buen vino para el convite, que comer $y$ no beber seria cegar y no vei, ni valdria todo un arclite.

Tanto I ázaro como Horozco liaman licol al vino: "Un poco cerrados los ojos por mejor gustar el sabroso liquor) (p. IOI). Horozco emplea el término con el mismo valor adjetival ${ }^{1}, \mathrm{y}$, en cierta ocasión, expresa la misma idea que el ciego cuando afirma que el vino sanaba toda enfermedad y descalabiadura de Irázaro:

No lo llamarcmos vino, mas otro liquor divino contra toda cuffermedad.

(Cancionero, p. 212)

Al iniciar el relato de sus andanzas con el ciego, nos hizo Lázaro una valiosa conficlencia: "Huelgo de contar a V. M. estas niñerías, para mostrar quánta virtud sea saber los honubres

1 "Tiéncos ya tan afinado / el licor de Sant Martin", Cancioncro, pígina 50. "Avicudo amor derramado/su venenoso liquor", Cancionere, p. 228. 
subir siendo baxos y dexarse baxar siendo altos quánto vicion (p. 9I). En ella encontramos un uso del juego conceptual bajar-subir aplicado a lo social que constituye una iclea medular en el Irazarillo, muy repetida también por Horozco, segrin ramos a comprobar.

Siente nuestro toledano que se viven tiempos de convulsión y crisis social; advierte que la vida la tomado un ritmo acelerado, inédito luasta entonces, y cuya resaca llega a su rincón provinciano, en el que desarticula y revuelve todo el sistema medieval de los "estados» sociales. Casi a morlo de símbolo, es la idea que informa la glosa del primer refrán: Anita agora el tiempo tal, que no sé cuál va tras cuál (II, p. 699), los ratones van tras los gatos, el señor sirve al criado, las mujeres mandan a los maridos:

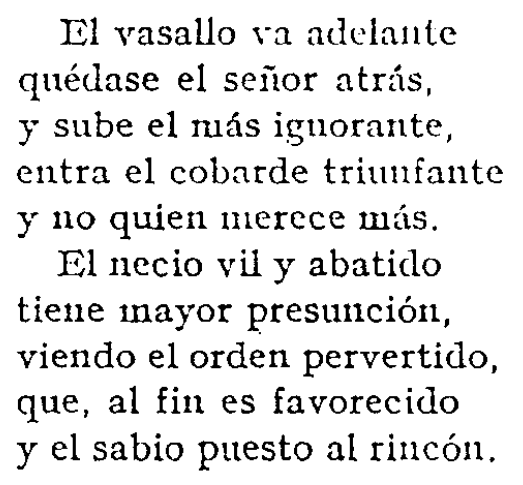

En tan babilónico desorden, los buenos bajan y los malos suben a los altos puestos: Abájanse los adarves y álzanse los muladares (II, p. 703). La ambición la calado hasta cu los nús ruines, que de repente se ven transformados en señores, dice Horozco cuando glosa Al ruin dalde un palmo y tomarse ha veinticuatro (III, p. I08, r. II9), aun sin venir muy a cuento:

\footnotetext{
Querer siempre mejorarse es la condición del ruin, y poco a poco ensancharse, hasta venir a quedarse, si puede, con todo al fin.
} 
$\mathrm{Y}$ el que vino pobre y calmo, hecho señor está ya, y sabe muy bien su salmo, porque, al rutn, dándole un palmo vcinticuatro tomará.

Cuando comenta $A$ quien quiere matar, mata, $y$ a quicn quiere sanar, sana (III, p. 402, r. 328), parece recordar Horozco el viejo tema medieval de la rueda de Fortuna:

Este inundo es un dislate, que a los que están en la cima derrueca abajo y abate, y a los bajos de quilate vemos que sube y sublima.

Pues la transformación va casi siempre en perjuicio de los niejores hombres, según describe la glosa de Da Dios hadas [¿habas?] a quien no tiene quijadas (III, p. 7I2, r. 629):

Veréis hombres muy prudentes, tan pobres y desechados, que da mancilla a las gentes ${ }^{1}$, $\mathrm{y}$ a otros muchos dementes muy ricos y sublimarlos.

La dualidad bajar-subir que ahora nos interesa es, ptues, comunísina en el Libro de Prowerbios. Carretillas son que ruedan (III, p. 595, r. 543):

Si el que tuvo prosperado se ve después abatido y cl bajo muy sublimado, es porque el mundo ha rodarlo y asi ha bajaclo y subido.

1 En seguida cruza por la imaginación la lástima de Lázaro por el escudero: "Aquéllos es justo desamar y aquéste de aver manzilla", (página 198). 
Más clara intención social reviste en Asićntate cu tal lugar que nadie te pueda echar (III, p. 405, r. 353):

Y asi, para no bajar, como muchas veces vi, asientate en tal lugar que nadie te pueda echar, antes te digan subir.

E1 Cancionero sigue insistiendo en el vicio del medro rápido y forzado:

El más pobre y desechado, a quien el mundo aborrece, puede ser tan fortunado que suba al mayor estado, como cada dia acontece.

(Pp. $175-176)$

Pero una importancia mayor tienen, a nuestro parecer, las coplas que escribió Horozco para celebrar la entrada de Siliceo en Toledo, como Arzobispo de la sede primada. Se le alaba - y quizás con alguna zumba - porque Dios ha querido premiar sus virtudes subiéndolo precisamente "a la cumbre» ${ }^{1}$ :

1 Una intención irónica es casi segura, dado lo que Horozco asociaba a este sube y baja. Incluso la mención de Dios no deja de ser sospechosa, pues era ya secreto a voces que la mitra toledana constituia el pago de sus servicios como responsable de la educación del futuro Felipe II. Horozco, cuyo genio no podía permanecer nucho espacio sin clavar los dientes en algo o en alguien, insinuó otras veces con malicia la ambición de Siliceo; cuando fue hecho cardenal en I $55^{6}$ comentaba: "Fiué cosa este capello para el arçobispo de harto plazer segund le estava deseando". Añade después que debia el nombramiento a haber tenido pensionado al cardenal Caraffa, que al convertirse en Paulo IV "vino a tiempo que se lo pudo pagar». CONDE DE CEDILLO, Algunas relaciones y noticias toledanas que en el siglo XVI escribia el Licenciado Sebastian de Itorozco, p. I83. In cuanto a lit mención de cumbre en Horozco: "Quien de casa te echara /y se subirí en la cumbre" (IV, p. 383, r. 704 ). "Cunbre subida de gran hermosura" (Cancionero, p. 62). "Antes que suba a la cumbre, / el remedio se le dé» (III, p. I09, r. I22). 
Por su grande merecer humildad y mansedumbre le vino Dios a poner subiendo de un baxo ser a lo alto de la cumbre.

Observemos la aparición de ese "subir a la cumbre" que inmortalizará el sarcasmo final del Lazarillo y cuyo interés aumenta al comprobar que se trata de una composición en la que desaparece la habitual inseguridad de la fecha, pues el mismo Cancionero nos advierte, en sus rúbricas, que tales coplas se hicieron con dicho motivo en I546, es decir, unos siete u ocho años antes de la aparición impresa del Lazarillo de Tormes.

\section{EL CLERIGO}

La avaricia es uno de los vicios más reciamente atacados por Horozco, y la gente de iglesia queda muy bien alcanzada por su crítica. Il fraile entra en religión para «mandar, guardar y adquirir" (II, p. 699), en remedo de los tres votos. E1 clérigo come, insaciable, diez o doce beneficios (II, p. 699-700). El Cancionero (p. I52) nos presenta en la Parábola de Sant Mateo la vida de escasez de los clérigos pobres que, como el de Maqueda, apenas si pueden reunir un mezquino ordinario:

\footnotetext{
Yo no sé quién ser desea mercenario, pues su mayor ordinario es ganar medio real. de pitança por salario, así que le es necesario vivir en el hospital.
}

Mientras que su interlocutor, el echacuervo que pide la 
cuesta de San Antón, se queja de que tampoco él puede reunir una blanca para vino ${ }^{1}$.

También se asocia el arca con el atesoramiento vicioso:

¿Qué provecho ha de hacer

al avariento que abarca

todo cuanto puede haber,

si cle ello no osa comer.

metido al rincón del arca?

(IV, p. 392, r. 773 )

$Y$ en el Cancionero (p. I2), al reirse de la desgracia de un avaro:

\footnotetext{
Salgan ora los doblones

sin resistencia ninguna,

qu'estaban en talegones,

en las arcas y bolsones.
}

$\mathrm{Y}$ cuando se burla de otro, al que luabía pedido algo y se hizo el sordo:

$$
\begin{aligned}
& \text { Pase todo por donayie, } \\
& \text { diziendo como al desgayre } \\
& \text { nichil in arca vazta. }
\end{aligned}
$$

(Cancionero, p. 262)

La misma asociación del arca con los bodigos de las ofrendas, puede haber sido sugerida por el refrán $A l$ fin parar al arca de los molletes (III, p. II6, r. I84).

Lázaro queda sometido a un racionamiento estrechísimo, con la agravante de que, encima, ha de soportar la comedia de

1 "Y descle ayer no he llegado/una blanca para vino", Cancionero, p. I53. Lazarillo: "De la taverna nunca le traxe una blanca de vino" (p. 135); podemos comprencer el carácter de miseria que Lázaro desea resaltar con ello; el escudero, para describir la mala suerte que le ha traido la casa, dice que desde que entró en ella no ha probado gota de vino (p. 204). Tanto el autor del Lazarillo como Ilorozco ticnen la misma afición a valorar las cosas en blancas y otras monedas de escaso valor. 
generosidad que el clérigo juega cuando, cada cuatro días, le da la llave para ir a coger una de las contadas cebollas ${ }^{1}$. Es lo que cabe esperar del hombre mísero, dice Horozco en la glosa a Dádiva ruin, a su dador parece (III, p. 7I3, r. 635):

Unu cicgo podrá juzgar ser verdad, aunque no vea, y aunque más quiera tirar, un ruin nunca puede dar dádiva que ruin no sea.

Porque si éste da un cuatrin, piensa que luego empobrece, y asi dicen bien al fin: Dádiva triste y ruin, a sil dador se parecc.

X más claramente en De casa de ruin, nunca buen aguinaldo (III, p. 720, I. 693):

El hombre zarracatín, que no se harta de caldo, no es para dar un cuatrín, $y$, en fin, de casa de ruin, nunca vi buen aguinaldo.

Donde además se da una intrigante coincidencia con el clérigo, que partía con el mozo su ración de caldo: «verdad es que partía comigo del caldon (p. I30).

Por otra parte, toda la cicatería del amo es inútil, porque

1 Ya vimos cómo se habla de las cebollas para extremar la nota de la mísera alimentación que el clérigo proporciona a Lázaro. Toda la novela está llena de los mismos detalles intencionados, no hay nada que salga simplemente del vielo de la pluma. El Lazarillo es obra pensadísima, escrita probablemente cuando ya se habia estructurado, hasta en sus inenores detalles, en la mente de su autor. Advirtamos cóno los episodios están ya encanninados desde sus primeras frases; cómo se cuenta, por ejemplo, el encuentro con el clérigo: "Fuyme a un lugar, que llaman Maqueda, adonde me toparon mis peccados con un clérigo" (p. 125), y con el escudero: "Topóme Dios con un escudero" (p. 166). 
el mozo hambriento siempre da con la forma de robarle. No hay que extremar ni tirar demasiado de la cuerda cn cicrtos negocios, aconseja Horozco al discurrir sobre Aprctar mucho las cosas, hace venir a perdellas (III, p. I3I, r. 300). I'or mucho que cuente y recuente sus bodigos, Lázaro termina remediándose con ellos, pues De lo contado come e! lobo (III, p.7 I6, r. 659):

\author{
Deléitase el avariento \\ con su tesoro en mirallo, \\ porque, como está hambriento, \\ toma por mantenimiento \\ muy a menudo contallo. \\ Mras, aunque con más cuirlado \\ lo cuente y guarde del robo, \\ muchas veces le es hurtado, \\ bien como de lo contado \\ se mantiene y come el lobo.
}

Los efectos de comicidad menudean y llegan al colmo en la esgrima a distancia que amo y criado mantienen en torno al arca de los bodigos. Al reflexionar, Lázaro destaca la poca perspicacia del clérigo, que no advierte lo improbable de la invasión ratonil: "Porque, si casa avía de aver en el reyno justamente de ellos privilegiada, aquélla de razón avía de ser, porque no suelen morar donde 10 ay qué comern (p. 152), lastimosa exención donosamente formulada en el comento de Al que no tiene el Rey le hace franco (III, p. I07, r. I06):

\footnotetext{
Quien no tiene qué pagar es más que privilegiado, y si le mandan pechar, con razón podrá alegar su privilegio rodado.
}

En general se advierte una decidida voluntad en hacer del clérigo el personaje más odioso del libro, por lo que que se le presenta no ya como glotón, mísero, cruel e hipócrita, sino también vulgar e ignorante. Nótese la mala intención con que se acoge textualmente su modo de hablar tosco y popula- 
chero: "Agora, donos traydores ratones, conviéneos mudar propósito, que en esta casa mala medra tenéys» (p. I49). Más aún, cabe sospechar que a lo mismo apunta la regocijada descripción de las nocturnas persecuciones en que el clérigo anda "hecho trasgo" ${ }^{2}$, espantando a la vecinclad mientras busca a la culebra, puesto que en los Proverbios (30, I8-I9) se alinea la búsqueda del rastro de una culebra entre las tres difficilia. Sobre dicho versículo discurre una composición del Cancionero (p. 235), y de esta manera se motejaría al clérigo de simple e ignorante ${ }^{2}$ de unas Sagradas Escrituras que debería conocer por ineludible exigencia del oficio.

Las semejanzas se acentuan al llegar el desenlace. El Cancionero (p. 202) contiene también una escena en que un criado es sañudamente golpeado durante el sueño, lo mismo que Lázaro sufre el tremendo garrotazo. Il mayordomo de Booz, deseoso de congraciarse con su señor, golpea a un gañán-que por cierto lleva el casi quinteriano nombre de Reventadopoco amigo de madrugar. Primero le amenaza:

$\Lambda \mathrm{fe}$, si tomo un garrote que yo te haga entender.

Y tras cambiar dicharachos con el soñoliento bracero, le propina una buena mano de coces, y el Reventado queda haciendo gran sentimiento:

Ay! ay!; ay de mí mezquino! que me ha descostillado.

1 También andaba hecho un duende casero todo el asunto referente a cierta moza poco cuidadosa de su castidad: "Lo que se clize contino / que parece duende en casan, Cancionero, p. 98. También recoge Horozco el castigo que se dió a unos sujctos que se fingieron duendes en una casa que deseaban comprar más barata (Cancionero, página 214).

2 Según M. Herrero Garcis, el Lazarillo «ataca la miseria intelectual del clero, ruralizado, avillanado, entregado por hambre en manos de los enenuigos del progreso, plebeyez y avezamienton. Nueva interpretación de la novela picaresca. RFE, XXIV, 1937, p. 355. 
Por su parte el clérigo, cuando descubre todo el artificio de Lázaro para procurarse unas migajas de pan, pone el grito en el cielo y se alegra de haber dado por fin con quien le destruía y comía su hacienda, en térninos tales, que parecen irónica variante de la glosa de Horozco a Del monte sale quien el monte quema (III, p. 7I7, r. 672):

Muchas veces acontece que, con tu misma hacienda, tu criado se enriquece, y ese mismo te empobrece sin que se sepa ni entienda.

A consecuencia del golpe, permanece Lázaro durante tres días uen el vientre de la ballena" y le atiende mientras tanto "una vieja que ensalmava", casta de gente bien conocida de nuestro Licenciado, que las retrata bien a lo pícaro cuando comenta Creo en Dios y no en pulas viejas (III, p. jII, r. 622):

Debémonos de guardar de viejas santiguaderas, que, so color de ensalmar, santiguar y saludar, soll muy grandes hecliceras.

Al verle recobrar el conocimiento, dice la experta vieja que "plazerá a Dios no será nada" (p. I63) y viene a estar de acuerdo con la apostilla De menos nos hizo Dios (IV, p. 394, r. 7I5):

\footnotetext{
Por muy grave enfermeclad que uno tenga y llegue al punto, si place a la voluntad de la divina Bondad, no le tengáis por difunto.
}

Anotemos, por último, una repetición casi literal: "Viéndome en tal estrecho" (p. I46). "Viéndone cn aqueste estrecho" (Cancionero, p. 95). 


\section{FI, TSCUDI:RO}

I.legamos a la médula genial del Lazarillo, en que los temas mís variados y complejos se formulan con una eficacia y perfección ilimitada, que parece incluso haber llevado la capacidad creadora del autor hasta su nivel de agotamiento. Ninuciosa y amorosamente pensado, no debe a priori de extrañarnos que el resto de la obra de su autor - sea quien fuere-ofrezca un número muy elevado de coincidencias muy cercanas a todo lo dicho en este episodio. Las que arroja una comparación con Horozco, son nuchas y de transparencia impresionante.

Advirtamos que la vida mísera y lacerada del escudero es anténtico lugar conún en IIorozeo. $A l$ parecer, la desgracia de estos hombres de armas era proverbial en aquel lugar y fecha, puesto que aparece ligada a gran número de refranes, que sin duda alguna influyeron en la elaboración del mcjor episodio del Lazarillo. Las glosas de Horozco acentúan todavía más el parecido; veamos la de $A$ esculero pobre, taza de plata $y$ olla de cobre (III, p. Ior, r. 6r):

Donde hay poco que gastar conviene y es menester con gran cuidado mirar y adquirir y granjear lo que se puede perder.

Y evoquemos a Lázaro, calle arriba, cuando su amo trajo a casa un real por primera y única vez, «echando mi cuenta en lo que le emplearía, que fuesse mejor y más provechosamente gastadon (p. 204).

El tópico de la pobreza escuderil se repite, pues, hasta la saciedad. A un pobre hidalgo, tres colradias y un galgo (III, p. 409 , r. 380 ): 
E.l pobre del escudero,

pues que ni compra ni vende,

ni cuenta mucho dinero,

ni sirve a algún caballero,

yo no entiendo en qué se enticnde.

Y más aún, otro refrán de glosa confusa, 1 esculcro pobre, rapaz adivino (III, p. ror, T. 62), asocia a la pobreza del escudero la presencia de un mozo que, al parecer, no le trae buenc suerte:

Siempre se le hace mal

al pobre del escudero,

que, con su poco caudal,

le da Dios un mozo tal,

que contino es agorero.

En la parte inédita del Libro de Proverbios cabe espigar algún otro que insiste en la pobreza del mozo del escudero: El moço de el escudero anda un año sin çapatos, despućs muele al çapatero ( $\mathrm{I}, \mathrm{f}{ }^{\circ} 789$ ), de gran interés si tenemos en cuenta que Lázaro cuida muy bien de decirnos que no usó zapatos hasta que, una vez terminada su aventura con el escudero, el fraile de la Merced le proporcionó el primer par (p. 226).

El Cancionero continúa suministrando datos en el mismo sentido. En una composición festiva rechaza Horozco un sablazo con la excusa de

que se ha tormado escuclero, y sobre todos sus males no hay en casa seis reales.

La simpatía, e incluso ternura, con que el autor mima la figura del escudero es un nuevo rasgo coincidente. Iil Coloquio de la merte con todas las edades y estados no ahorra palabras duras al referirse al papa, al rey, al emperador y demás personajes acostumbrados en la danza, pero, al llegar al escudero, 
surge una excepción. La descarnada le trata con tino casi maternal:

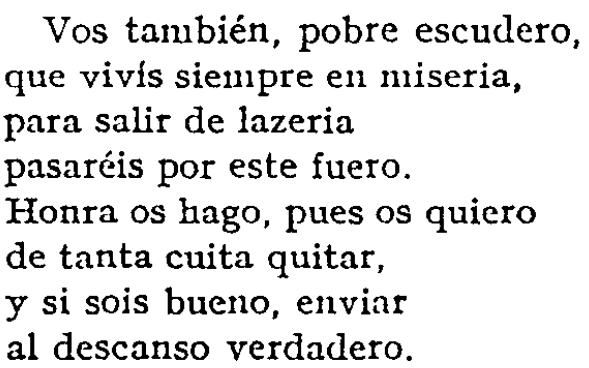

(Cancionero, p. rgi)

En I560 abundaban en Toledo, al olor de la corte, muchos tipos cuya subsistencia era también poco menos que misteriosa:

Hay tanto del holgazán sin oficios ni señores ni sin tener sólo un pan, pregunto, ¿qué comerán si no son garduñadores?

(Cancionero, p. 184)

Y en una sátira contra la moda de los coches, se pone en ridículo la manía que afecta hasta a las mujeres más pobres:

Hasta la del escudero quiere ya doquier que va que la lleve su cochero.

Cejador (p. I78, nota 2) advirtió ya cómo en un esbozo satírico (Cancionero, p. 209) dirigido a "1n galán que reventaba de hidalgon se ríe Horozco de lo poco que le aprovecha venir de alto linaje y "presumir de caballero" cuando se encuentra tan falto de pan en su casa y de dinero en la bolsa.

El tema del orgullo y presunción ${ }^{1}$ aparece igualmente

1 La presunción es, en general, vicio fustigadísimo por Horozco. "¿De qué tienes presunción, / hombre mundano y terreno". III, pá- 
claro. Entre los refranes coleccionados por Horozco hay uno donde esa presunción aparece también como proverbial: Escudero de lança en puño, mucha presunción y dinero ninguno (f. ${ }^{\circ}$ Io). También se encuentra en Horozco la burla contra los signos de tal presunción, como ocurre con el urazonable» vestido; del amo de Lázaro podría decirse aquello de Bien galante andas, mas buena hambre te pasas (III, p. 4I5, I. 423):

Es tanta ya la locura de la gente vana y loca, que el más bajo y vil procura tener mejor vestidura aunque lo ayune la boca.

En el comer muchas tasas y las misiones escasas, y en el vestir te desmandas; así que, bien galán andas, mas buena hambre te pasas.

Y también puede entenderse su actitud ofensiva hacia el oficial que intentó saludarle con el familiar Manténgaos Dios:

Anda agora el mundo tal, que no está ya vividero, porque el más ruin oficial quiere en todo ser igual con el mejor caballero.

Entre los privilegios de la dudosa cofradía del grillimón se encuentra igualmente el de poder saludar sin el bonete muy bien quitado, como quería el escudero:

gina 402, r. 330. "En cocles con presunción / van a las cosas divinas", Cancionero, p. 245. "Vos con vra. presunción / tenéis tan dañado el gusto", Cancionero, p. $2 \mathrm{I}$. "Y con esto se han alçado/ las putas con presunción", Cancionero, p. I83. "Hay hombres que, en presunción, / son muy grandes caballeros", III, p. I20, r. 2 Ir. "Cada cual, por ruin que sea, / quiere tener su opinión, / pundonor y prestunciónn, III, página 427, r. 502 . 
Iten: que en el saludar no quede por mal criado el que no pudiere alçar el braço para quitar el bonete acostumbraclo.

(Cancionero, p. 3)

La confidencia que de sus asuntos privados hace a Lázaro, proporciona además nueva semejanza al referirse al palonar "que a no estar derribado como está, daría cada año más de dozientos palominos" (p. 2I3), pues Horozco comenta sabrosamente el refrán Cebo tenga el palomar, que palomas no han de fallar (III, p. 596, r. 552):

Haya dineros sobrados $y$ en casa bien que gandir. que aunque estén amotinados no nos faltarán criados que nos vengan a servir.

$Y$ pues andan a buscar estos tales su cebillo, Cebo tenga el palomar que en él no pueden fallar palomas con el granillo.

Notó Cejador ${ }^{1}$ la semejanza notable que ofrecen las pullas del autor del Lazarillo contra las malas costumbres de los hidalgos toledanos, muy amigos de solazarse en las frescas mañanas por las orillas del 'lajo, donde no les solía faltar alegre y placentera compañía de "reboçadas mujeres», que, en sus ratos de moralista, sacaban de quicio a Horozco, pues congratula al predicador Firay Antonio Navarro - el de la famosa empanada - por su sermón contra las tapadas, con el que mo-

1 Pág. I85, nota 2. La semejanza fue, como siempre, negada por COTARELO, que añade el mallimorarlo comentario: "No parece sino que no se podía hablat de alnuterzos en el Tajo sino con permiso de Horozco" (II, p. 684). 
vió al corregiclor a prohibir tales atavíos so pena de pérdicla de los rebozos (Cancionero, p. 243).

Toda la deliciosa vida privala de Irizaro y el escurlero en el interior de la casa lóbrega y oscura, está llena de sabrosos detalles que la obra del abogado toledano puede ayudarnos a comprender en toda su profundidad. En la figura del escudero pretendió crear el autor un contraste, lleno a la vez de lástima y comicidad, entre las pretensiones y apariencias a que socialmente se ve compromsticio por razón de su "estado", y las circunstancias reales, que le fuerzan a pasarto mucho peor que un mendigo ${ }^{\text {; }}$ en el fondo es el escudero un obligado tránsfuga social, y alguios refranes nos lo hacen ver muy claro. Sabía Horozco que un hombre de armas no podía comer lo mismo que un gañán, y a su erudición jurícica no escaparían sin duda alguna los texíos medievales que estatuían del noble comer y puntillosa eti(gueta de la mesa icl caballero ${ }^{2}$.

1 El citado artículo de Margarita Morrcale contic ne latos que demuestran la realidad de la plaga de hidalgos y escuderos sin sconor a quien servir ni rentas de que mantenerse. I,o que ocurria es que en Castilla, como en todas partes, esta infima nobleza se hallaba en trance mortal a consecuencia de la nueva estructuración conónica y politica de los tiempos modernos; Horozco, que los aborrecía profundamente, concentra su benevolencia sobre la figura de estas víctimas, simbolos de la sociedad medieval que era ya inviable.

2 Pueden verse, por ejemplo, las prescripcioncs que la Orilen de la Banda, creada por Alfonso XI, imponía a sus calalleros. "M[ucho deve extrañar todo Cavallero de la vauda de non conter minjares sucios, ca de los buenos ay asaz en que se pueda bien mantencr: et otrosí porque hay algunas frutas e ortalizas torpes e sucias, que guarden eso mesmo de non las comer... Otrosi debe guardarse de non comer ninguna vianda sin nanteles, salvo si fuere letuario of futa, o andando a caza o en menester de guerra. Et otrosi en el beber que guarde estas tres cosas. I, a primera que nunca beba en pie, salvo si bebiere agua; la segunda que nunca beba vino en cosa cle barro, nin de madero; la tercera que guarde, que non se santigüe con el vaso, o con la taza que bebiere". LORENzo 'TADEo Vilianueva, Memoria sobre la orden de caballeria de la Banda de Castilla. BRAH, t. IXXII, I9I8, pág. 557. A excepción del último, no dejó nuestro escudero de contravenir ni uno solo de estos mandamientos. 
Prestemos atención a las quintillas que glosan $A l$ villano, puerro y ajo, y no manjar blanco (III, p. IIg, r. 206):

Los manjares cxtremados, los pavos y los faisanes, los potajes y guisados, son para los delicados, y 110 para los gañanes.

Mas la cebolla y tasajo, por mesa el poyo o el banco, para gente de trabajo, Y al villano, puerro y ajo, $y$ no le den manjar blanco.

Recordemos que, cuando el infeliz se come las ruines viandas que su mozo le ha mendigado, lo hace sentándose, sin ceremonia alguna, "al cabo del poyo" (p. I9x), hombro con hombro de Lázaro (p. r93), con lo que se ha pretendido medir la magnitud de su bancarrota social. De un modo idéntico se comporta cuando ordena a Lázaro invertir inmediatamente el solitario real con que, de inexplicable modo, se había hecho: «Ve a 1a plaça y merca pan y vino y carne: jquebremos el ojo al diablo!n (p. 203), pues nos dice Horozco que tal conducta es la que cuadra a cualquier hambriento ganapán:

Iil pobre del oficial en alcanzando que alcanza a tener algún real, aunque vaya al hospital ha de entrar todo en la panza.

(III, p. 597, r. 560)

Por lo demás, el escudero es un perfecto insensato. Fiado en sus cuentas galanas ha abandonado su tierra contra el prudente consejo del refrán Bien te cstabas en tu nido, pájaro pinto (III, p. 4I4-4I5, r. 422): 
$A$ las veces, hombre deja

su propia casa y asicnto y en otras tierras se aleja, adonde después se queja de haber hecho mudamiento.

Que es exactamente lo que él hace, y menos mal que, contra su costumbre, no tiene inconveniente en reconocer que no le ha sucedido como pensó. I,levado de su orgullo ridículo y desaforado, se mete en inutiles porfías con personas poderosas, sin notar lo poco que le va en todo ello:

En lo que va poco o nada, querer hombre porfiar es cosa muy excusada.

$($ IV, p. 396, r. 796$)$

El mismo hecho de haber tomado para sí un criado, demuestra cumplidamente su escasez de mollera, pues it pai y' cebolleta no cumple tañer trompeta (III, p. I32, r. 30I):

Si el hombre honrado no tiene por ventura que comer. porque no se sepa y suene, no le cumple ni conviene llamar quien lo pueda ver.

Muy mejor es que se meta donde no le han de entchder, porque, a pan y cebolleta no cumple tañer trompeta ni convidados tener.

Sanísimo consejo para las "personas de vergüenza" cuando andan mal de cuartos $y$ que reitera Aja no tiene que comer $y$ convida giiespedes (III, p. 4ro, r. 3S6):

No teniendo facultad el que la cosa comienza. antes hace necedad que no liberalidad. si es persona de vergiienza. 
Los dos uiltimos refranes tienen interés tanto mayor cuanto que muestran ese sentido de la pobreza como vergiienza social, que, a pesar de todo, mantiene en pie al escudero y es causa de que nos unamos al autor en su cariño y velada admiracióll. Bien miraclo, se trata del úlico vestigio heroico que el Lazarillo deja incólume, del único voluntarismo humano que en todo él ha podido resistir el agua regia del hambre. $Y$ es, en suma, lo mismo que predica Horozco al plantear el dilema Ayunar o comer trucha (III, p. I04, r. S7):

Cualquier que quiere vivir en bucn estofa y manera, debe mucho de advertir que no se debe abatir a cosa baja y ratera.

Porque es poca la ganancia y la infauia será mucha; naide peque de ignorancia y tenga siempre constancia de ayunar o comer trucha.

Pero, a su vez, el escudero también es capaz de pasar a la ofensiva y plantear con la mayor finura los fallos de la más alta clase dirigente, por lo que la emprende con el vicio, tan renacentista, de la adulación y el hediondo clima moral que ésta trae siempre consigo. Toda la graciosa y afilada pintura de la vida del escudero con el señor de título ${ }^{1}$ y las ventajas e

1 González Palencia veia en esta sátira de la vida palaciega una posibiliclad de sumar puntos a favor de la paterniclad de Hurtado de Mendoza. Por otra parte es muy notable el modo cómo el lexicógrafo Covarrubias, hijo, no lo olvidemos, de Sebastián de Horozco, redacta su artículo sobre escuderos: "E,n la paz los escuderos sirven a los señores, de acompañar delante sus personas, asistir en la antecámara o sala; otros se están en sus casas y llevan acostamientos de los señores, acudiendo a sus obligaciones a tiempos cicrtos. Oy día más se sirven dellos las señoras; y los que tienen alguna passada huelgan más de estar en sus casas que de servir, por lo poco que medran y lo mucho que les ocupann. Tesoro de la lengua castcllana, ed. MAR'TiN DE RIQUER, Barcelona, 1943, p. 543. 
inconvenientes de su servicio, queda también csbozada por Horozco. Veamos el comentario de $A$ bien te haré mezquino (II, p. 703), con su reproche del proceder de los señores y condena del servicio a merced:

A mercedes ni favores nunca sirvas, mientras puedes, pues que ves que los señores hoy dia, a sus servidores hacen muy pocas mercedes.

Pues ya no se cotiza sino a truhanes ${ }^{1}$ parlanchines y aduladores, Al hombre mudo todo bien le huye (III, p. II8, r. I96):

No puede medrar un pan

el hombre que hoy es callado; conviene ser charlatán, $y$ entonces todos le dan y de todos es premiado.

$\mathrm{V}$ ser callado y sesudo a nccedad se atribuye, más vale obrar de agudo, pues vemos que al homore mudis todo bien se va y se huye.

La coincidencia con el escudero del Lazarillo es evidente: "Y no quieren ver en sus casas hombres virtuosos; antes los aborrescen y tienen en poco y llaman nescios y que no son personas de negocios ni con quien el señor se puede descuydar» (p. 2I7). Cualquier chocarrero es sistemáticamente preferido al hombre de conciencia:

Un bueno no alcanza un pan, aunque venga de los godos, y una puta y un truhán, un loco y un charlatán, halla cabida con todos.

1 In I 560 trajo consigo la corte "un mundo de truhanes", (Cancionero, p. 184). 
Amargo comentario al refrán A la puta y al truhán, perdido es cuanto le dan (III, p. I2I, r. 2Ig) al que dedica una glosa inusitadamente extensa (seis quintillas), que demuestra la irritación de Horozco y que no reproducimos íntegra por mera razón de espacio. Abunda eil lo mismo Andaos a decir verdades, iréis a los hospitales (III, p. I28, r. 272):

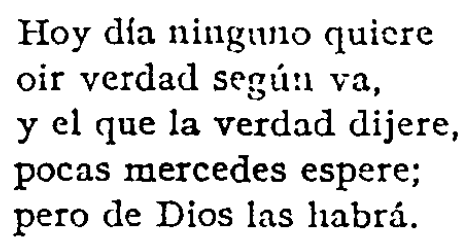

$\mathrm{Y}$ en $A$ quien dice la verdad luego le dicen que rabia (III, p. 402 , r. 329$)$ :

Como no hay quien quiera oir

la verdad ni por semejas, no hay quien la sepa decir; todos se dan a mentir porque aplace a las orejas.

Es ya tanta la maldad, que ya dicen que es de Babia el que no usa de ruindad, y al que dice la verdad lucgo le dicen que rabia.

En la escenificación de la historia de Ruth vemos a un criado poner en práctica las intenciones del escudero: «Y ponerme ha reñir, donde lo oyesse, con la gente de servicio, porque pareciesse tener gran cuydado de lo que a él tocava" (p. 216). En efecto, el avispado mayordomo de Booz piensa desp ués de haber recibido las órdenes de su señor:

A mil ine conviene hoy poner manos a labor, porque vea mi señor quíu bucna maña me doy.

(Cancionero, p. 201) 
Tras de lo cual la emprende a coces, como vimos, con el infeliz gañán Reventado.

Volviendo al escudero, hemos de ver que, como ha señalado Bataillon ${ }^{1}$, toda su picaresca se limita y reduce a inventar absurdas excusas para no comer. Es el hombre de las nexcusas no válidas» (p. I86), como dice Lázaro cuando le ve canıbiar de color y "hacerse izquierdo" ${ }^{2}$ ante las pedigüeñas ninfas de las riberas del Tajo. El hambre queda mal encubierta por admoniciones a la templanza y pretextos más o menos rebuscados e inverosímiles: "Pues, aunque de mañana, yo avía almorzado $y$, quando ansí como algo, hágote saber que hasta la noche me estoy ansí) (p. I 7 r), ignorando el refrán Bonicos andamos: si comemos, no cenamos (III, p. 4I8, r. 45I):

\footnotetext{
Los que renta no tenemos ni quien de comer nos dé y trabajar no queremos, si algún día bien comenos, otro no tenemos qué.
}

Asegura que prefiere las uñas y tripas al manjar más elegante, al mismísimo faisán. Todo ello, pura inversión humorística de Achaques al viernes por no aymnalle (II, p. 705).

La aparición del escudero convidando liberalmente a su mozo con el jarro de agua debía ser mucho más regocijada para los que conocían sobradamente el refrancejo Más quería vino en barro que agua en otro mejor jarro (t. II, f. ${ }^{\circ} \mathrm{I}_{4} 89$, r. I796). $\mathrm{Y}$ un relieve similar adquieren ciertos pasajes que de otra forma pueden pasar desapercibidos, como ocurre con aquél, tan circunstanciado, que nos relata el descubrimiento que hace Iázaro de la bolsa de terciopelo raso y sin blanca, guardada por el escudero debajo de las ropas de la cama; un refrán glosado

1 Le Roman picaresque, p. 6.

2 Es expresión de Horozco, cuando aconseja al mancebo cuerdo que no acceda a caprichos de damas, III, p. 103, r. 80.

21 
por Horozco, y que éste recuerda en alguna otra parte ${ }^{1}$, se lamenta: iAy del raso cuando empela y del pelo cuando enrasa! (III, p. I04, r. 90). Toda una elegía va comprimida en la simple mención de la bolsa de terciopelo raso.

La conducta de Lázaro puede aclararse de un modo similar. Por un momento surge en él la habitual reacción de adelantarse al abuso del amo, cuando temió que se comiese todo el pan: "Y como le sentí de qué pie coxqueaba, dime priessa. Porque le vi en disposición, si acababa antes que yo, se comediría ha ayudarme a lo que me quedasse) (p. I74), discretísimo soliloquio que parafrasea al refrán $A$ poco pan, toma primero; a chica cama, échate en medio (III, p. I3I, r. 296), cuya segunda parte no se atrevió ya a seguir Lázaro. Al día siguiente, completamente ganado por simpatía hacia su famélico señor, busca la forma más delicada de ofrecerle su ración uporque sentí lo que sentía y muchas vezes avía por ello passado y passava cada día” (p. Igr), expresión similar a la de Horozco cuando descubre a su protector su grave situación de descubierto con los proveedores:

Ya vra. mercea stá al cabo de lo que siento, y pues tan poco le va sé que todo lo hará al pie desta un libramiento.

(Cancionero, p. 97

1 En "el auctor a uno que traya un jubón quarteado de raso $y$ terçiopelo": "Por tanto dize que apela / de servir en vra. casa, / y dirá quien dél se duela, / iay del raso quando empela / y del pelo quando enrasal", Cancionero, p. 2 . De las bolsas rasas y sin blanca se burla también en Bolsa sin dinero, digola cuero (III, p. 4I 8, r. 446): "Si la bolsa está vacia, / tan rasa como la palma, / mientras blanca no tenia, / con mucla razón podria / llamarse cuerpo sin alma». La del escudero cra concretamente una bolsilla de terciopelo raso, hecho cien doblezes y sin maldita la blanca ni señal que la oviesse tenido mucho tiempo" (p. 197). 
Lázaro decide, por fin, "ayudarle, pues se ayudava» (p. I92), aplicando el refrán Ayudate y ayudarte he (III, p. I04, r. S8).

Algún refrán nos orienta igualmente hacia la aventura del muerto. Tal nos hace pensar el 475: Buscar la vida, que la muerte ella se viene (III, p. 423, r. 475):

Pues sabemos que ha de entrar la muerte por nuestra puerta.

La puerta que Lázaro atrancó con todas sus fuerzas para evitar la macabra visita (p. 206). Toda la escena del llanto de la viuda aparece repetida en Horozco, que la describe como una de las mogigangas que se vieron por Toledo en el año $1555^{1}$ con motivo de las rumbosas y casi interminables fiestas con que se celebró la conversión de Inglaterra.

Por último, no abandonaremos este fértil terreno sin rccoger un hallazgo efectuado en la parte inédita del Libro de Proverbios. Se trata de una linda miniatura en la que el infeliz escudero aparece redivivo como por obra y gracia del maestro Azorín; la glosa de La mujer del escudero, gran bolsa y poco. dinero (t. II, f. ${ }^{\circ}$ I206-08, r. I465), dice así:

1 "Este día salió una muy solemne máxcara, aunque por e tiempo a algunos nos [ ¿110?] paresçió bient, todos a cavallo y con su música, en que iva un cavallero degollado con la cabeça cortada y caida hazia tras, y muchos enlutados con él. Venia la muger enlutada llorando y pidiendo justicia con una soga al pescueço. Venian muchas mugeres descabelladas llorando y messándosen. CEDILLO, Algunas relaciones $y$ noticias toledanas que en el siglo XYI escribla el Licenciado Sebastián de Horozco, pág. I 75. "Dexo el camino que llevava y hendí por medio de la gente" (p. 206), dice Lázaro. Horozco: "Iistava la çapatería y todas las calles así por las ventanas como por baxo tanta gente que no avia quien pudiese hendern, $o p$. cit., p. 1 $7^{2}$. No faltaron en dichas fiestas de $\mathrm{I} 555$ ridículos actos de presunción: "Y un çapatero para sólo este día domingo aver comprado un rroçin por diez mill maravedís, aunque por ventura no los tenia de caudal ni de hazienda", p. I73. 
Cosa es averiguada que el pobre del escudcro, aunque trae espada dorada, no tiene blanca sobrada, sino muy limpio el esquero.

El procura compañia y buena conversación, platica en su hidalguia y llégase el mediodía y no ay pisca de ración.

Luego comiença a contar de la guerra de Navarra, y por no aver qué maxcar para la hambre pasar echa nano a una guitarra.

La triste de la nuger, viendo en casa tal apero y cómo no ay qué comer. dice que quisiera ser nutuger de un vil çapatero.

Veréys como él la consucla: señora, esperá un tantico porque me ducle una misela, y dadune acá essa vigiiela, tañeros le un villancico.

Assí que es muy berdadero aquel refrán tan usado, la muger del escudero, gran bolsa y poco dinero, rape el diablo el cornado.

Ante tan deliciosa escenita nos limitamos a puntualizar las más notables coincidencias. Atendamos a la fanfarria de la hidalguía y la mención de la hermosa espada. De casado continúa siendo el hombre de las excusas: no come por causa de un dolor de muelas. La técnica cuyo aprendizaje inició, con Lázaro, se ha refinado notablemente; los reniegos y el hambre de la esposa se ahogan entre las cadencias de un rillancico, con dulce y castizo acompañamiento de vihuela. 


\section{EL IFRAIIE DE IA MIERCED}

"Desenvolvió Horczco en su Cancionero lo que aquí puso en cifra solamente», dice Cejador comentando este tratado en esbozo. Nos parece oportuno comprobar lo cierto de su afirmación.

Reprueba mucho el Licenciado Horozco la mescolanza de las personas de hábito en negocios mundanos y poco edificantes - "amicíssimo de negocios seglares" era el nuevo amo de Lázaro. Las glosas hacen una pintura muy vivaz de esta casta de malos religiosos. Abad y ballestero. No concuerdan la citara y el salterio (II, p. j03):

Bien parece el sacerdote en su iglesia y en su templo, $y$ no andar liecho virote de tal arte que se note por hombre de nual exemplo.

Mucho más radical se nuestra Horozco cuando conenta Al abad que anda muy giieco, soga nueia, alinendro seco (III, p. III, r. I40):

Bien parece en el altar y en la iglesia' el sacerdote, no por las calles andar vestido como scglar, puesto de espada y capote.

Perdóneme Dios si peco, pero siempre oí decir: al abad que anda muy güeco, soga nuev'a y almendro seco donde se pueda medir.

Condena asimismo ane scan arrendadores y tratantes, en cuyo caso aconseja lo del refrán De clérigo negociador huye como pestilencia (III, p. 72I, r. 697). 
En el Entremés contenido en el Cancionero es, sin embargo, donde Horozco se ensañó más a su gusto al presentar la figura zafia y hampona de su fraile glotón y andariego. Anotemos el pasaje que ya impresionó a Cejador:

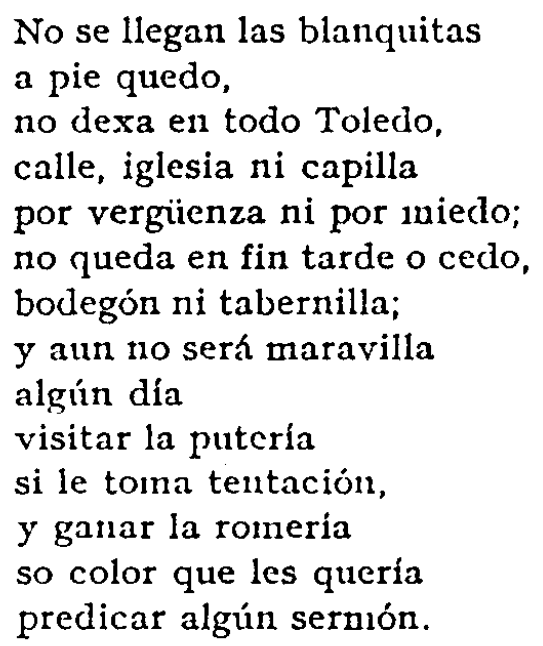

(Cancionero, P. 17I)

En cuanto al otro breve tratado que contiene la servidumbre de Lázaro con un alguacil, puede resaltarse nueva coincidencia con su momento más sobresaliente: 1a huída ante las pedradas de los retraídos. También las glosas de Al loco y al toro, dalle corro (III, p. I07, r. II3) y Afuera y cantos (III, p. Ior, r. 66), hacen la apología de la fuga y aconsejan quitarse de en medio en tales ocasiones.

\section{EI, BULDERO}

Pulsamos también un resorte crítico para Horozco, que nos da una impresión muy directa de la poca simpatía que todo lo que oliese a bulas despertaba entre las gentes del pueblo, de ese espiritu de resistencia pasiva que el industrioso buldero hacía saltar con sus trapazas y que permanecía vivo 
muchos años después, en plena época tridentina ${ }^{1}$. I a actitud escéptica aparece muy claramente definicla en el refrán Ajo puro y vino puro; bula no, que sacan prenda (III, p. I05. r. 95), cuya glosa, dividida en dos partes, termina por decir que tal postura es cosa de necios e ignorantes:

Porque si ellos tuviesen algún tanto de prudencia, está claro que quisiesen trocar cuanto poseyesen por la menor indulgencia.

Atenuación que parece dictada más bien por prudencia -ya vimos que el tiempo no estaba para bromas- que por convicción, pues Horozco vuelve a expresarse sobre las bulas en forma irónica y desabrida. Al criticar la manía de las mujeres en ponerse don, afirma que no les importaria pagar por usarlo, mejor que por bulas ni jubileos:

Porque por se autorizar son tan grandes sus deseos, que habiéndoles de costar, preciaran más se endonar que bulas ni jubileos.

(Cancionero, p. 240.)

$Y$ ninguna bula papal es poderosa para dejar de pertenecer a la cofradía del grillimón (Cancionero, p. I).

La explotación de la credulidad de las buenas gentes ${ }^{2}$ está

1 En un auto de fe de 1570 , historiado también por Horozco, salió "Juan Ortiz, çapatero vezino de Mombeltrán, porque se disfraçó en carnestollendas con hábitos de frayle con una tabla en la mano pintada una mala visión de hombre, diziendo que le diesen para San Cumus y para Santa Lucia y que besasen alli y ganarian quarenta dias de perdón». Fué castigado a salir con vela, soga y sufrir cien azotes. CEDrLLO Toledo en el siglo XVI, ap. X, p. 207.

2 Es lo que dice Rodulfo: "Pues entre la gente buena / no faltará para cena, / ello está bien acordadon, Cancioners, p. I5I. Ein el Entremés se increpa al fraile que pedia para las ánimas y se gastaba las limosnas en vino y golosinas: "La buena gente lo of rece / pensando que 
claramente formulada en la Parábola de Sant Mateo, donde los pícaros soldados se hacen pasar por cautivos de Argel para excitar la compasión:

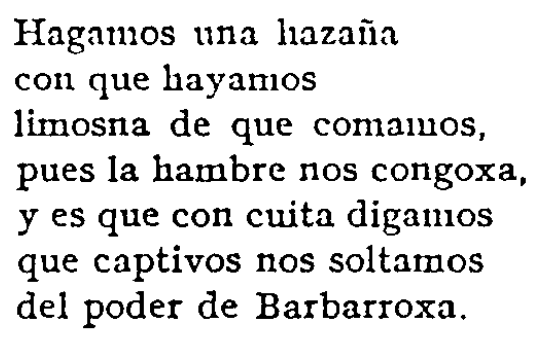

(Cancionero, p. 151)

$\mathrm{Y}$ merece la pena destacar que una de las bulas que predicaba el amo de Lázaro se destinaba precisamente a la redención de cautivos ${ }^{1}$.

No obstante, las semejanzas de más bulto surgen en uno de los cuadros que forman la Parábola de Sant Mateo, donde se nos descubren las picardías de un cuéstor de San Antón. La charla que sobre asuntos profesionales entabla con su reciente amigo el mercenario, versa acerca de su vivienda ${ }^{2}$, que es

le aproveche, / que a vos padre poco os questa", Cancionero, p. I75"Y quando de all se escapa / cúrale la buena genten, Cancionero, página I12. "Cuando no habia tanto mal / como agora se consiente, / trataba la buena gente / a la llana, Juan Pascual,, III, p. Io6, r. I0o. En el Lazarillo: "Con ayuda de las buenas gentes, di comigo en esta insigne ciudad de Toledo", p. I65. "Fuyme por essa ciudad a encomendarme a las buenas gentes", p. 189.

1 "Hermanos mios, tomad, tomad de las gracias, que Dios os embia hasta vuestras casas, y no os duela, pues es obra tan pía la redenpción de los captivos christianos, que están en tierra de Moros. Porque no renieguen nuestra sancta fe y vayan a las penas del infierno, si quiera ayudaldes con vuestra limosna y con cinco Pater nostres y cinco Ave marías", p. 244; y más adclante: "Pues, por vida del Licenciado Paschasio Gómez, que a su costa se saquen más de diez cautivos", p. 247. El interés es mayor por hallarse tales textos entre la parte interpolada en la edición de Alcalá.

2 "X mi vivienda es ecliar/la questa de Sant Antón", Cancionero. p. I 53. "Fácilmente se podría / alcanzar por esta vía / la vivienda que hicieres», IV, p. 39r, r. 765. En el Lazarillo: "Quiso mi mala for- 
echar "la questa de sant Antón» y añade en seguida que la poca devoción ${ }^{1}$ de la gente le hace pasar días sin vender una escoba ni reunir para un trago de vino. El mercenario le aconseja perversamente:

Si soys echa-cuervo fino,

dad acḱ, esta questa predicá, decid que venis de Roma;

desta unanera quiçá alguna persona avrá que caiga con que hombre coma.

Cuando aparece el venerable viejo que es el Padre de las Compañas, le espeta la consabida hipócrita petición:

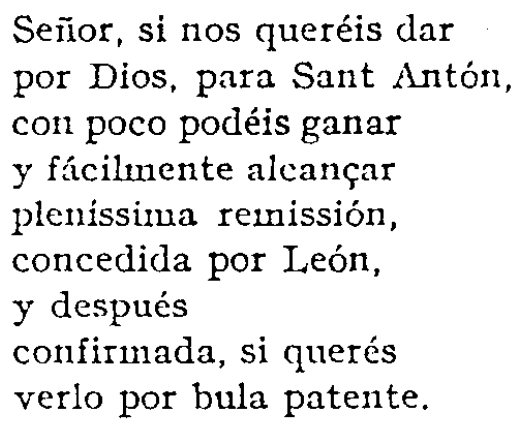

$\mathrm{Y}$ lo más grave es que el anciano - el mismísimo Padre Eterno- se limita a reprenderles secamente su holgazanería:

Hermanos, mejor harés trabajar pues que podés, que andaros ociosamente.

(Cancionero, p. 153)

tuna... que en aquella trabajada y vergonçosa bivienda no durasse", páginas 199-200.

1 "X hay tan poca devoción / en la gente, / qu'aunque ande diligente / y corra más qu'una posta, / e aunque trabaje y revicnte, / aún no puedo amargamente / allegar para la costan, Cancioncro, pígina I53. El buldero también encontraba poca caridad: "Que por la poca charidad que en el pueblo avia, la cruz ardla", p. 250. "Que por la poca charidad, que avía en ellos, avia Dios permitilo antuel milagron, p. 250. 
A nuestro juicio, todo cl pasaje merece la más honda atención en cuanto puede conducirnos de nuevo a una coincidencia con Masuccio de Salerno. En efecto, los textos publicados por Foulché ${ }^{1}$, muestran también al desaprensivo Fra Girolamo engañando a las bucnas gentes con una bula falsa que, según él, garantiza la autenticidad de la reliquia que trae consigo; para mayor eficacia - sicólogo cien por cien-se la saca repentinamente de la bocamanga y la pone ante los ojos de quienes está seguro que no se atreverán a comprobarla. La falta de acotaciones que, como en todo primitivo del teatro, se da en Horozco, no nos permite asegurarlo, pero a pesar de ello el pasaje deja entrever una maniobra semejante; adviértase que, hasta el momento en que llega el de las Compañas, no se menciona para nada la existencia del documento y el tono en que hasta entonces ha hablado el echacuervo se emplea precisamente para demostrar la altura de su moralidad, de la que cabe esperar cualquier engaño. 'lodo nos hace creer que, en el peor de los casos, no parece prudente descartar como posible el que Horozco conociera, por cualquier camino, la obra de Masuccio.

\section{TODO FAVOR Y AYUDA}

$\mathrm{Y}$ ya tenemos, por fin, a Lázaro en el camino de la prosperidad y en el escalo de la cumbre de la buena fortuna. Sus desvelos le costó, pero pudo echar mano a su oficio real "con favor que fuve de amigos y señores" (p. 256), frase que no creemos haya sido puesta allí a humo de pajas.

Cabe preguntarse seriamente hacia dónde apuntan los tiros contenidos en este último tratado. Que el término de la sátira en capítulos anteriores está colocado en el bajo clero, o en la pequeña nobleza, aparece perfectamente claro. Pero

1 R.Foulcuí-Deibosc. Remarques sur Lazarille de Tormes. RHi, VII, 1900, pp. 8I-97; So, nota. 
¿y en este episodio del Arcipreste de San Salvador? Advirtamos como primera providencia que su contenido anticlerical es sólo secundario. Los defectos de ambos cleros y los abusos, como el vergonzoso tráfico de bulas, han siclo ya expuestos. Notemos, después, que el protector de Iázaro 110 es un simple clérigo, sino todo un Arcipreste, un micnubro de la jerarquía eclesiástica, y en una época en que ésta era una fuerza por completo incorporada a la dirección de la vida española ${ }^{l}$, $\mathrm{y}$ este hecho nos parece mucho más digno de relieve que su carácter de persona eclesiástica. ¿Van los tiros entonces contra el propio Lázaro? Sólo en cierto modo, pues, al fin y al cabo, no tenemos más remedio que considerarlo siempre un poco o un mucho víctima del medio social.

A nuestro parecer, el autor pica ahora mucho más alto que en los tratados precedentes. Se nota pronto que lo que en él ha querido denunciar es toda aquella política del favor que en unos cuantos años pudrió a lo largo y a lo anclio, lepra o cáncer irremisible, todo el cuerpo social de la monarquía de los Austrias. Lo que se propone el autor es, así, colocarnos ante ojos y narices la repugnante anatomía, la dinámica interna de todo favor y ayuda (p. 259) ${ }^{2}$. La crítica de todo un sistema que comenzaba en las cercanias de la misma persona real y descendía, de un escalón en otro, hasta el pregonero de Toledo. Lázaro liasta entonces ha podido conservar, incluso en el seno del hambre, una razonable personalidad que se desmorona al contacto con el corrosivo del favor, de la ayuda cómoda y fácil que una criminal complacencia pone al alcance

1 No digamos de la vida de Toledo, acurrucarla ya toda ella a la sombra de las magníficas rentas de su mitra. Se lia elegido a un canónigo porque en Toledo era difícil imaginar algún otro magnate mús influyente y rumboso.

2 Véase la última copla de los privilegios de la cofradía del grillinón: "X porque su devoción / no quede sin premio y pago, / será su congregación / su junta y adrocación / en Toledo o cn Santiago; / do el general comisario / y el grand administrador, / como se haze ordinario/les dará lo necesario/y toda ayuda $y$ favorn, Cancionero, p. 4. 
de aquellas manos, quc habían llegado a mendigar el alimento de alguien en el fondo más desdichado que él. Cuando se rebela débilmente contra el lamentable statu quo de su vida matrimonial, el Arcipreste -el polleroso social- le recuerda ladino: "No mires a lo que pueden dezir; sino a lo que te toca, digo a tu provecho" (p. 263). I ázaro no insiste porque recuerda el "bien y favor" que de tal persona le podía venir y piensa que su señor "me ha prometiclo lo que pienso cumplirá» (p. 262), misterioso y último favor que Lá7aro ya no no se atreve siquiera a desvelarnos.

Repugnaba a Horozco hasta la exasperación todo este inframundo de miseria noral, doblemente doloroso en cuanto iba engulléndose a un gran pueblo. He aquí su glosa del castizo Alla van leyes do quicren reyes (III, p. IO7, r. II2):

Las leyes y sus rigores se ejecutan en pobretos, mas los grandes y señores, y los que ticnen favores, a ellas no están sujetos.

Su mentalidad de hombre de toga se encrespa sientpre que roza el mismo tema. Cormudo y apaleado (III, p. 7I2, r. 627):

El pobre desventurado, como no tiene favor, aunque sea el injuriado, ha de ser el castigado $y$ ha de llevar lo peor. $Y$ si me quieres creer, aunque fuese el afrentado, deberia no contender, porque, en fin, tiene de ser cornudo y apalcado.

El mito del favoritismo y cel enchufe penetraba ya hasta lo más inferior del cuerpo social. Hasta el pedazo de bestia del villano del Entremés sabe que, con faiorcs, puede llegar a clonde le parezca: 
$\mathrm{Y}$ aun quien a mi me parió

para obispo me crió.

son que no tengo favores.

(Cancioncro, P. I6 6 )

Como era de esperar, Horozco profesa verdadero asco a la Corte, fuente suprema de esta cadena de males. Véase, si no, su malhumorada versión de la estancia de la Corte en Toledo, el año 1560 . No hay incomodidad, lucro ni corrupción que no haya venido con ella (Cancionero, p. I82-I85) y una plaga de parásitos anda al olor de los favores, de aquellos oficios reales que eran el único medro sin posible quiebra:

Unos sirven de abogados, $y$ otros pretenden oficios cansados y aperreados, aunque tengan los cuytados los favores muy propicios.

Todo está ya tocado "con esta florezica de privar y de subir» (Cancionero, p. 186 ):

Hay un mundo de truhanes de que no hay quento ni suma, chocarreros charlatanes hay infinitos galanes de capa, y espada, y pluma.

Hay nuchos paseadores que se andan a sus vicios, y que pretenden favores de Príncipes y señores para conseguir oficios.

(Cancionero, p. 184 )

La Corte ha llevado a la remansada vida toledana una auténtica inversión de valores, en la que la sombra de la persona real lo justifica todo por sí misma. Cualquier miembro de la servidumbre del Rey se permite insolencias con las personas más dignas de respeto: 
Mas agora un vil portero nos habla con magestad, y el más triste despensero se ha de contentar primcro. qu'el mejor de la cibdad.

$\mathrm{Y}$ este punto podríamos prolongarlo cuanto quisiéramos.

Son muchísimos los pasajes en que Horozco se divierte con chocarrerías y pullas relativas al amancebamiento de clérigos y frailes. Alguno de ellos fué ya denunciado por Cejador, como aquellas coplas en que "Reprehende el auctor a un cornudo porque se casó con una manceba de un clérigo y después también sufría el cuerno» (Cancionero, p. 9) o en "El auctor a un Bachiller, que se casó tres vezes, habiendo sido todas tres mugeres rabicalientes y las dos mancebas de dos canónigos) (Cancionero, p. 2I2). Ėn ambas, más que el tema del amancebamiento, nos interesa comprobar cómo la complacencia del esposo se liga a la percepción de favores. En la primera le reprocha duramente:

Holgaisos con este mote por comer bodigos tiernos sin pagar por ello escote, pero guardaos del açote con una sarta de quernos.

Fragmento en el que interesa apreciar que el precio de la vista gorda son precisamente los bodigos que el abad recibe como ofrenda de los fieles, y que se contaban entre los mezquinos regalillos que Lázaro y su mujer recibían del Arcipreste: "X siempre en el año le da en vezes al pie de una carga de trigo, por las pascuas su carne y quando el par de los bodigos, las calças viejas, que dexa» (p. 259-260). En el segundo caso, el Bachiller recibe en premio nada menos que un corregimiento -jel favor!- y Horozco le señala, como más indicado, el de Cervera.

E1 Cancionero contiene además unas coplas "a una dama que en muriendo el marido se amancebó con un fraile» (p. 28) 
y la «burla de un casamiento que un su conocido dixo que le trayan» (p. 6) propone también:

Daros han una donzella aunque dizen qu'es parida.

En el mismo caso que la mujer de Lázaro, de quien se murmuraba que "avía parido tres veces" (p. 239). Las coplas a favor y en contra de las mujeres les reprochan también que

$$
\begin{aligned}
& \text { So color que son casarlas } \\
& \text { hazen deshonestidades, } \\
& \text { estando con los abades } \\
& \text { claramente annancebadas. }
\end{aligned}
$$

(Cancioncro, pp. $72-7.3$ )

$Y$ aprovechan su estado matrimonial para uno poder ser marcadas». En la unisma Representación Euanjélica, cuando los incrédulos rabies preguntaban al padre del ciego si es aquél su hijo, responde el viejo:

Si no tuvo parte el cura en él quiçá, mi hijo es y. será.

(Cancionero, p. 164)

$\mathrm{Y}$ hasta la respuesta al doctor Rodríguez "porque dixo que avia cierta tierra donde un durazno y una pera eran tan transparentes, que puestos al sol se veían las pepitas y las rayitas del quexco», da ocasión a un chiste sobre el mismo tema:

Yo sospecho que tencr transluzientes propiedades es porque deben nazer de árboles, que suelen scr por dicha bijos de abades. 
Amigo de zaherir a sus conciudadanos, cuando discurre sobre "la alcabala de la canina, que dizen haberse pedido en tpos. pasados en esta cibdad de Toledo" (Cancionero, p. 259), no perdona la ocasión de recurrir a su chocarrería predilecta:

$$
\begin{aligned}
& \text { Pues conviene el ojo abrir } \\
& \text { en estos tpos. modernos, } \\
& \text { que ya debe de venir } \\
& \text { tpo. en que se ha de pedir } \\
& \text { alcabala de los quernos. } \\
& \text { Y según ja hoy dia } \\
& \text { se usa aquesta !nadera, } \\
& \text { yo fío que no seria } \\
& \text { la que menos montaría } \\
& \text { en 'oledo, y donde quiera } \\
& \text { En la qual por no pagar } \\
& \text { de diez uno, digo yo } \\
& \text { se podrian encabeçar } \\
& \text { aquí y en qualquier lugar } \\
& \text { muchos que piensan que no. }
\end{aligned}
$$

Balín del mismo calibre que el de Iázaro al afirmar que la suya ues tan buena muger como vive dentro en las puertas de 'Toledo" (p. 265), si bien nada de esto parece haber hecho mucha mella, pues, cuando en 1555 celebraron en Toledo las fiestas por la conversión de Inglaterra, se divertieron lindamente con una lamentable máscara ${ }^{1}$ que el mismo Horozco nos describe con toda puntualidad.

I "Y porque en este dfa ay poco que contar, es de saber que en uno de los primeros dias de las fiestas salió una máxcara de dos en sendas mulas y con una trompeta delante muy enlutados, y en las caperuças altas de luto que llevavan, sacaron cada uno un par de quernos muy bien puestos. Y llevava cada uno su rrét.ılo, el uno que dezíc Atendite et videte si est dolor sicut dolor meus, y el otro que dezia Solatium est miscris socios habere penarum. II trompeta también llevava ull cuerno en la cabeça. Eista maxcara tan peligrosa sacáronla dos mançebos, porque si fueran casados no es de creer que osaran burlarse con el cuernon. CEDict,o, Algunas relaciones y noticias toledanas que en el siglo XVI escribia el Licenciallo Scbasticin de Horozco, página, 176 . 
En cuanto a la postura, falsamente inocentona, de Lázaro, parece que se ajusta bien a aquello de $A l$ buen hombre llaman cormudo (III, p. IIf, r. I66):

Manso es su sobrenombre, porque a nadie hace guerra, $y$ por dino de renombre, al sermejante buen hombre llaman cornudo en mi ticrra.

Su actitud ante la murmuración, la del dicho De mi digan y a mi pidan (IV, p. 384, r. 7II):

Mas querríalo yo ser, aunque los ruines lo impidan y hártense de roer, que, teniendo de comer, de mi digan y a mi pidan.

Y para terminar, transcribiremos la versificación de un caso parecidísimo al de Lázaro, contenida en la glosa del refrán 854 de la parte aún inédita:

El abbad y su manceba $y$ el herrero y su muger, de tres huevos comen dos; esto cómo puede ser.

Si quiés saber por entero de este caso la verdad, la que es mujer del herrero es manceba del abbad $y$ ambos tiran a un terrero.

Assí que no es cosa nueva a quien lo quiera entender, el abbad y su manceba $y$ el herrero $y$ su muger son tres personas de prueba.

Mientras el herrero maja, el abad leer la beza, después el otro trabaja mientras el clérigo reça con atestarle la paja. 
Luego siéntanse a comer

los señores reverendos

con su manceba y ninger.

De tres güievos cómense dos, de este modo puede ser.

(T. I, f. $702-705)$

Idilica versión del buen amor y compaña en que Lázaro y su mujer "los domingos y fiestas casi todas comían en su casa” (p. 235).

Llega el momento en que hemos de reflexionar acerca de cuanto llevamos expuesto, de plantearnos el problema de cuál es el valor de todas estas coincidencias entre Horozco y el autor del Lazarillo de Tormes. ¿Casualidades? ¿Constantes de época? No lo creemos. Los puntos de contacto son demasiado numerosos y demasiado importantes para ser fruto de una mera coincidencia ambiental. Apenas si hay en el Lazarillo un tema literario, un tópico, un pensamiento, un recurso expresivo que no pueda encontrarse también en Horozco. Pensemos, además, que tales paralelismos no proceden de un solo campo, que lo que hasta ahora hemos podido investigar en cuanto a fuentes, lengua y estilo tiende a arrojar los mismos resultados, que daremos a conocer a su debido tiempo.

Se pondrá la objeción de nuestro desconocimiento de la cronología que rige la obra de Horozco, de la posibilidad de que muchas de las coincidencias expuestas puedan ser posteriores a la aparición impresa del Lazarillo, y de hecho algunas lo son con toda seguridad. Pero hay otras que con la misma certeza son también anteriores a 1554 , y de aquéllas que no podemos fechar es preciso reconocer que un cierto número habrán de ser ulteriores y otro número, igualmente indeterminado, citeriores a dicho año, puesto que sabemos, por propio testimonio, que las aficiones literarias de Horozco despertaron con su mocedad, y en ese terreno de aluvión que es el Cancionero, hay obras de I545. E1 Lazarillo fué conocidísi- 
mo a partir de 1554 , pero aun después chay algún otro escritor que haya estado, como Horozco, tau obseso por los temas que en él se exponen? ¿Lo estaba acaso su otro presunto autor, don Diego Hurtado de Mendoza? Los datos de que hasta ahora disponemos nos fuerzan a responder sin vacilación, y negativamente, a ambas preguntas. $Y$ desde luego, lo que no puede afirmarse en modo alguno es que hasta ahora haya sido rebatida la teoría de Cejador; por el contrario, los datos de carácter externo son, como hemos visto, netamente favorables a Horozco. Estimamos por ello que, hasta el momento, hemos de considerar a Horozco, por lo menos, como el más calificado aspirante a la paternidad del Lazarillo.

Confesamos, por último, lo arduo de nuestra labor, pero también lo grato de toda ella. Cuando se da una cultura en la que, como dijo nuestro filósofo, casi todo lo bueno es anónimo, apenas si puede imaginarse trabajo más atrayente que el que nos ocupa. Y en grado máximo, cuando el premio de nuestro esfuerzo puede ser el gran enigma de ese yo que, simbólicamente, inicia el Lazarillo. Y la novela moderna.

$$
\text { Francisco Márquez Vilianueva. }
$$

Universidad de Sevilla. 